\title{
INFLUÊNCIA DA MATÉRIA ORGÂNICA SOBRE O CALCÁRIO APLICADO AO SOLO
}

\author{
ISABELLA CLERICI DE MARIA
}

Orientador: Prof. Dr. ZILMAR ZILLER MARCOS

\begin{abstract}
Dissertação apresentada à Escola Superior de Agricultura "Luiz de Queiroz", da Universidade de São Paulo, para obtenção do título de Mestre em Agronomia. Area de Concentração: Solos $\theta$ Nutrição de Plantas.
\end{abstract}

PIRACICABA

Estado de São Paulo - Brasil

Abril - 1986 


\section{AGRADECIMENTOS}

Ao Prof. Dr. Zilmar Ziller Marcos, pela orientação e estímulo.

Ao Prof. Dr. Valdomiro Bittencourt

Ao Prof. Dr. Toshiaki Kinjo

$\bar{A}$ Prof ${ }^{a}$ Drạ. Elke Jurandy Bran Nogueira Cardoso

Ao Dr. Carlos Cerri

A ESALQ, em especial ao Departamento de Solos, Geologia e Fertilizantes .

Ao Centro de Informática na Agricultura

Aos funcionārios do Departamento de Solos, Geologia e Fertili$z$ antes e do CENA.

Ac CNPQ pela bolsa de estudos concedida

A todos aqueles que de maneira direta ou indireta contribuiram para a realização deste trabalho. 


\section{INDICE}

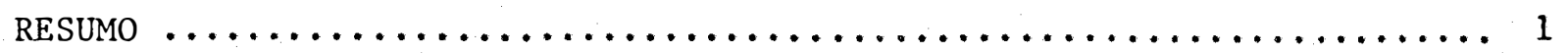

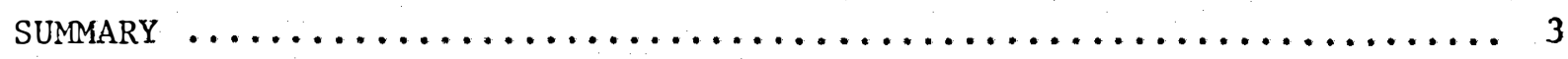

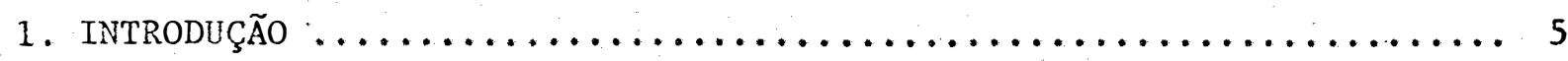

2. REvisÃO DE Literatura $\ldots \ldots \ldots \ldots \ldots \ldots \ldots \ldots \ldots \ldots \ldots \ldots \ldots \ldots \ldots \ldots$

2.1. Solubilização do Calcário $\ldots \ldots \ldots \ldots \ldots \ldots \ldots \ldots \ldots \ldots$

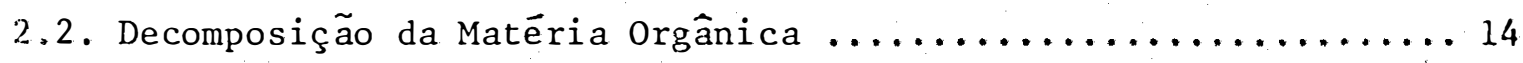

2.2.1. Medida da taxa e extensão da decomposição ......... 15

2.2.2. Fatores que afetam a decomposição $\ldots \ldots \ldots \ldots \ldots \ldots$

2.2 .2 .1 . Temperatura $\ldots \ldots \ldots \ldots \ldots \ldots \ldots \ldots \ldots \ldots$

2.2.2.2. Grau de umidade e aeração $\ldots \ldots \ldots \ldots \ldots \ldots \ldots 17$

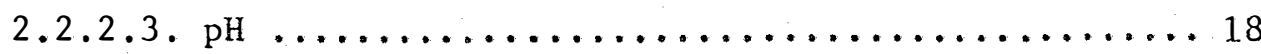

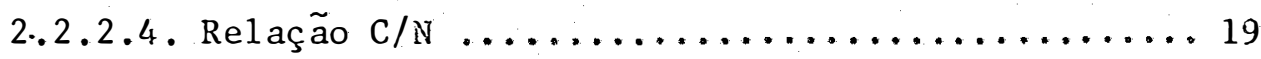

2.2.3. Influência da Matéria Orgância sobre o pH do Solo ..... 21

2.2.4. Atividade Microbiana e Solubilização de Minerais ...... 23

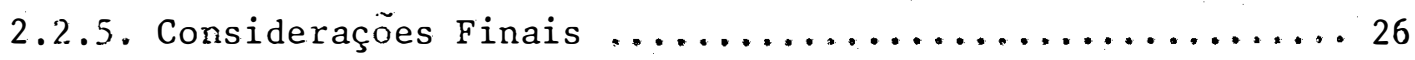

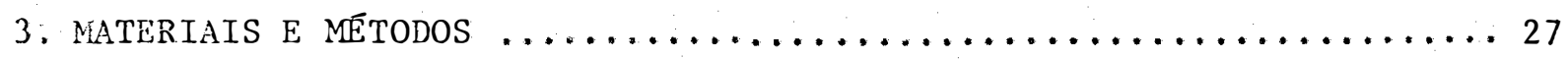

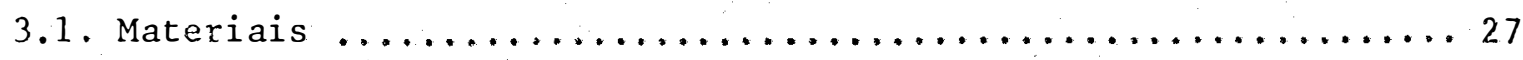

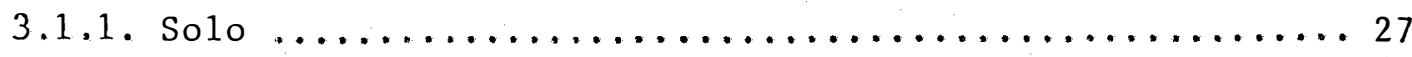

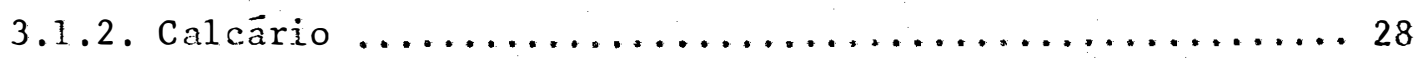

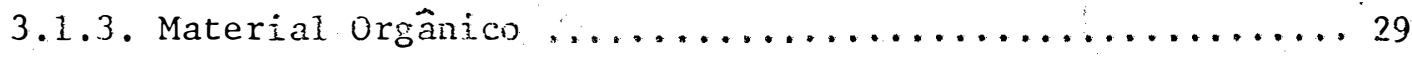

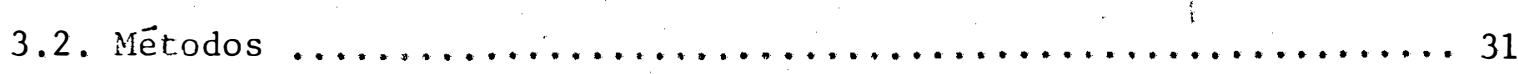

3.2.1. Método Experimental ..................... 31

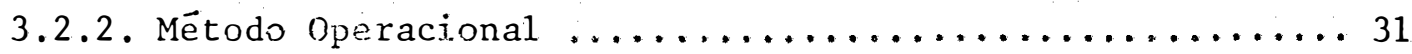


3.2.2.1. Determinação da dose de calcärio ......... 32

3.2.2.2. Determinação do teor de água para incubação ... 33

3.2.2.3. Montagem dos tratamentos $\ldots \ldots \ldots \ldots \ldots \ldots \ldots$

3.2.2.4. Medida da evolução do $\mathrm{CO}_{2}$ do solo ......... 38

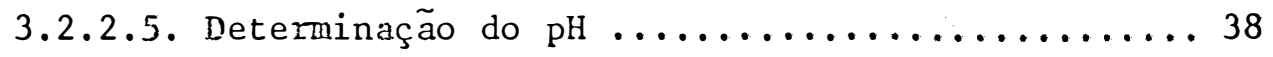

3.2.2.6. Determinação dos teores de cálcio e magnésio trocāveis ........................... 38

3.2.2.7. Condutividade elétrica .............. 39

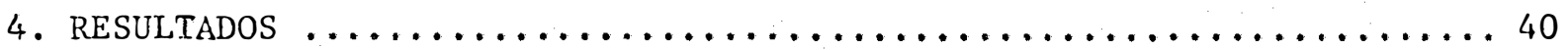

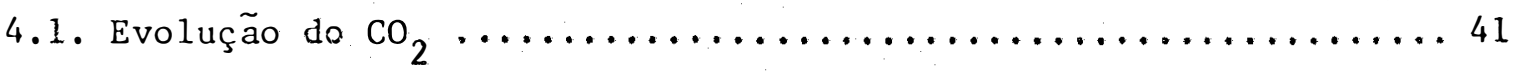

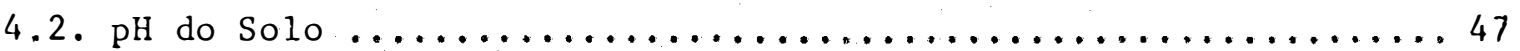

4.3. Cäicio e Magnésio Trocáveis ..................... 50

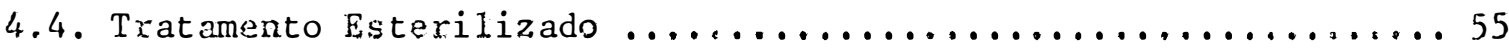

4.5. Percta de Água ............................... 59

4.6. Condutividade elétrica .......................61

4.7. Efeito da Restrị̧ão Imposta à Livre Difusão $\ldots \ldots \ldots \ldots \ldots . \ldots 6$

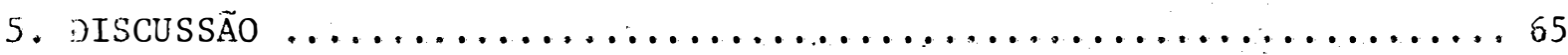

5.1. Evolução do $\mathrm{CO}_{2}$ nos diferentes tratamentos $\ldots \ldots \ldots \ldots \ldots \ldots 66$

5.2. Alterações no $\mathrm{pH}$ provocadas pela matéria orgânica .........69

5.3. Hipçtese 1: A presença no solo de matéria orgânica em decomposiçăo aumenta a solubilização do calcärio ....... 72

5.4. Hipótese 2: A produção de $\mathrm{CO}_{2}$ pelos microrganismos aumenta a solubilização do calcário .............. 74

6. CONCLUSÕES $\ldots \ldots \ldots \ldots \ldots \ldots \ldots \ldots \ldots \ldots \ldots \ldots \ldots \ldots \ldots \ldots \ldots \ldots$

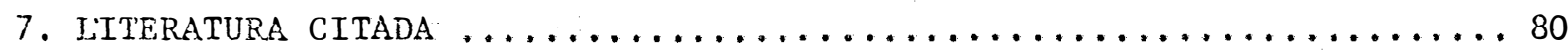




\section{LISTA DE QUADROS}

1. Análise química do solo Terra Roxa Estruturada, série "Luiz de

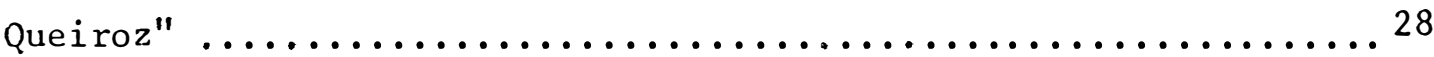

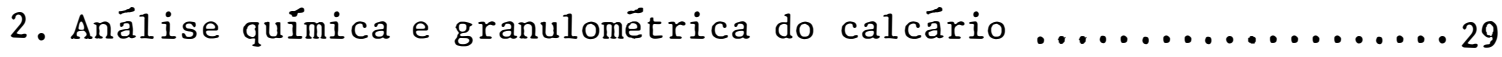

3. Teores de carbono (\%) e nitrogênio (\%) e relação $\mathrm{C} / \mathrm{N}$ dos mate-

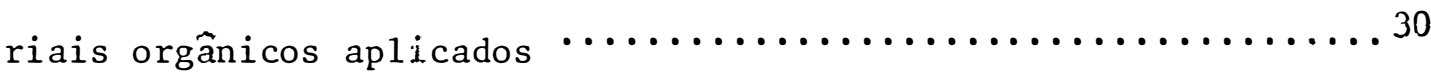

4. Teores de āgua (\% de peso seco) que foram utlizados na incuba-

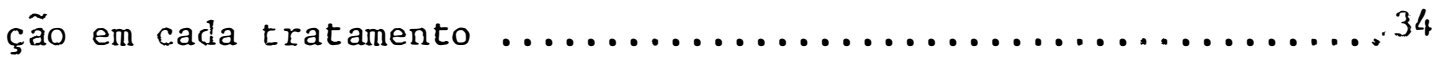

5. Valores de temperatura $\left({ }^{\circ} \mathrm{C}\right)$ māxima (M) e mínima (m) diäria registrados durante o decorrer do experimento e a temperatura

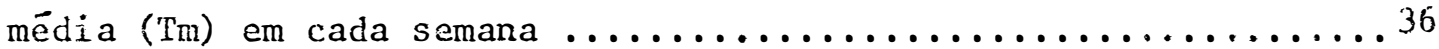

6 . Teores de $\mathrm{CO}_{2}$ (mg $\mathrm{CO}_{2} / \mathrm{g}$ solo) 1 iberados por semana em cada um

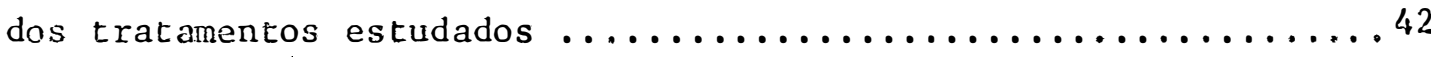

7. Teores acumulados de $\mathrm{CO}_{2}$ ( $\mathrm{mg} \mathrm{CO} / \mathrm{g}$ solo) liberados em cada um dos tratamentos estudados $\ldots \ldots \ldots \ldots \ldots \ldots \ldots \ldots \ldots \ldots \ldots \ldots$

8. Teores de carbono (mg C/g solo) inicial, evoluído e final, e a porcentagem de carbono perdido na forma de $\mathrm{CO}_{2}$, em relação ao teor inicial, para os tratamentos estudados...............46

9. Valores de $\mathrm{pH}$ obtidos semanalmente para cada tratamento (média de três repetições), e valores de $\mathrm{pH}$ no início da incubação $($ Tempo zero $=$ To $)$. Resultados da análise estatística: valores de F, da DMS de Tukey e do coeficiente de variação 
10. Valores de cálcio trocāvel (meq $\mathrm{Ca}^{2+} / 100 \mathrm{~g}$ solo) obtidos quinnalmente em cada tratamento (média de três repetições). Resultados da anālise estatística: valores de F, da DMS de Tukey e

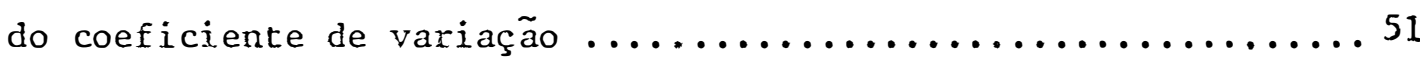

11. Valores de magnésio trocável (meq $\mathrm{Mg}^{2+} / 100 \mathrm{~g}$ solo) obtidos quinzenalmente em cada tratamento (média de três repetições). Resultados da análise estatística, valores de F, da DMS de Tukey e do coeficiente de variação..................... 52

12. Valores de pH dos tratamentos esterilizado (ESTER) e testemunha (TEST) obtidos semanalmente (média de três repetições).Resultados cả análise estatística: valores de F, da DMS de Tukey e do coeficiente de variação...................... 57

13. Valores de cālcio e de magnésio trocáveis dos tratamentos esterilizado (ES'TER) e testemunha (TEST) obtidos quinzenalmente (média de três repetições). Resultados da anālise estatística: valores de F, da DMS de Tukey e do coeficiente de variação.....58

14. Quantidade de ägua (g) colocada por frasco pra suprir as perdas por evaporaçäo em cada tratamento (média de três repetições) Resultados da anālise estatística: valores de F, da DMS de Tukey e do coeficiente de variação ...................60

15. Condutividade elétrica (mohos/cm) determinada, para cada tratamento nas três ültimas semans: X, XI e XII (média de três repetições). Resultados da anālise estatística: valores de F, da DMS de Tukey e do coeficiente de variação .............62 
16. Valores de pH (mẻdia de 5 repetições) nos tratamentos do experimento fatorial $2^{2}$ calcário $x$ difusão do ar. Valores de $F$, da DMS de Tukey e do coeficiente de variação .............64 


\section{LISTA DE FIGURAS}

1. Quantidade de $\mathrm{CO}_{2}$ (mg $\mathrm{CO}_{2} / \mathrm{g}$ solo) evoluído a cada semana nos tratamentos com $5 \%(1 \mathrm{~A})$ e $10 \%$ (1B) de matẻria orgânica........45

2. Valores de $\mathrm{pH}$ obtidos a cada semana nos tratamentos com 5\% (2A) e $10 \%$ (2B) de matēria orgânica........................ 49

3. Teores de cälcio trocāvel (meq $\mathrm{Ca}^{2+} / 100 \mathrm{~g}$ solo) obtidos quinzenalmente nos tratamentos com 5\% (3A) e 10\% (3B) de matëria

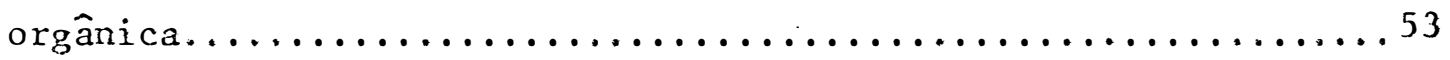

4. Teores de magnésio trocável (meq $\mathrm{Mg}^{2+} / 100 \mathrm{~g}$ solo) obtidos quinzenalmente nos tratamentos com $5 \%$ (4A) e $10 \%$ (4B) de matêria orgânica................................ 54

5. Valores de $\mathrm{pH}$ obtidos nos tratamentos do experimento fatorial

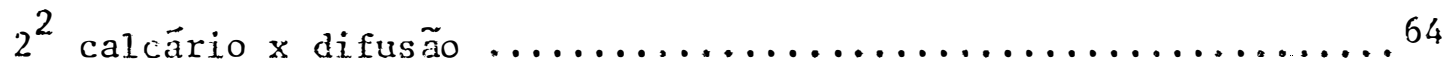




\section{Influencia da Matéria Organica sobre o Calcário aplicado ao}

\section{SOLO}

Candidato : ISABELLA CLERICI DE MARIA

orientador: Prof. Dr. Zilmar ZizIer Marcos

\section{RES SUMO}

Para verificar a possível influência da matéria orgânica em decomposição sobre o efeito corretivo do calcário no solo, atravēs do $\mathrm{CO}_{2}$ e outros produtos da atividade microbiana, foi montado um experimento em condiçöes de 1 aboratório.

Ao horizonte A de uma Terra Roxa Estruturada, série "Luiz de Queiróz", aplicou-se calcärio dolomítico (6,3 ton/ha) e quatro tipos de material orgânico: soja, composto, palha de mi.lho e bagaço de cana. Incluiu-se um tratamento testemunha, sem adição da matéria orgânica, e um tratamento esterilizado com clocofórmio.

o tempo de incubação foi de 12 semanas, e a cada semana foram analisados: evoluçäo do $\mathrm{CO}_{2}$, pH e cálcio e magnêsio trocäveis.

Os resultados indicaram que a presença da ma- 
téria orgânica em decomposição aumentou a solubilização do calcário. A quantidade de $\mathrm{CO}_{2}$ produzida nos diferentes tratamentos não teve correlação com os teores de $\mathrm{Ca}^{2+}$ e $\mathrm{Mg}^{2+}$ trocāveis, indicando que não houve aumento na solubilização do calcário devido ao aumento na produção de $\mathrm{CO}_{2}$. Outros produtos da atividade microbiana são responsāveis pelas diferenças entre tratamentos. 


\title{
The Influence of Organic matter on Agricultural Limestone
}

\author{
Candidate: ISABELLA CLERICI DE MARIA \\ Adviser : Prof. Dr. zilmar Zizler Marcos
}

SUMMART

This study was conducted with the specific purpose of testing the validity of the assumption that decomposing organic matter affects the neutralizing effect of agricultural limestone through the $\mathrm{CO}_{2}$ and other products resulting from soil microbial activity.

A large earth sample taken from the Ap horizon of a "TERRA ROXA ESTRUTURADA" (Structured Roxa Soil) was uniformly treated with dolomitic limestone (at the rate equivalent to 6.3 ton/ha). Various organic materials identified as soybean (leaves and branches), compost, corn straw and sugar cane bagasse were added to sub-samples, These were applied individually to the sub samples at the rates of $5 \%$ and $10 \%$. A no-organic matter and a chlorophorm-sterilized treatment were added for control. All subsamples were incubated for 12 weeks under standard 1 aboratory conditions and weelkly analysed for $\mathrm{CO}_{2}$ evolved, pH and exchangeable $\mathrm{Ca}^{++}$and $\mathrm{Mg}^{++}$. 
Analysis and interpretation of the results indicated that decomposing organic matter increased 1 imestone solution whereas the amount of $\mathrm{CO}_{2}$ released through bio-respiration could not be related to the amount of exchangeable $\mathrm{Ca}^{++}$and $\mathrm{Mg}^{++}$. It was postulated that other products released during organic matter decomposition participate in the resulting $\mathrm{pH}$ and exchanglable $\mathrm{Ca}^{++}$and $\mathrm{Mg}^{++}$observed for the various treatments. 


\section{INTTODUÇÃO}

Inümeros estudos tệm sido realizados a procura de informações sobre a taxa na qual o calcārio altera a acidez do solo e 1 ibera íons cälcio e magnésio para o solo. A intaior parte desses trabalhos visa analisar o efeito da granulometria e da composição química do caleảrio sobre a sua reação com o solo. Mas outros fatores também podem alterar essa taxa de reação.

Sabe-se que a solubilização do carbonato de cälcio das rochas calcārias é um processo que, na natureza, ocorre com a participação do gäs carbōnico dissolvido na àgua. E conhecido, também, o efeito de ácidos orgânicos e inorgânicos, produzidos por microorganismos, na solubilização de rochas pouco solüveis.

Tendo-se em conta que a decomposição da matê-ria orgânica incorporada ao solo 1 ibera gás carbônico ( $\left.\mathrm{Co}_{2}\right)$, ācidos orgânjicos e inorgânicos, e diversas outras substâncias 
decorrentes da atividade microbiana, considerou-se a hipótese de que o calcārio agrícola, colocado no solo para correção da acidez, poderia ter sua taxa de solubilização afetada pela presença de matēria orgânica em decomposição.

Este trabalho de pesquisa procura verificar, experimentalmente, a possível influência da matëria orgânica em decomposição e da atividade biolögica sobre a ação do calcärio no solo, na correção da acidez e na liberação de ỉons cálcio e magnésio. 


\section{REYISÃO DE LITERATURA}

Neste ítem, são apresentados alguns aspectos gerais da solubilização do calcärio no solo e da decomposição da matêria orgânica com o intuito de mostrar as observaçōes que levaram à formulação das hipöteses deste trabalho.

2.1. SOLUBILIZAÇ ÃO DO CALCĀRIO

o calcärio aplicado ao solo para a correção de acidez tem, como constituintes principais, carbonatos de câlcio e de magnêsio: $\mathrm{CaCO}_{3}$ e $\mathrm{MgCO}_{3}$. Esses carbonatos são muito pouco solüveis em ägua pura. E a presença de anidrido carbônico $\left(\mathrm{CO}_{2}\right)$, dissolvido na ägua, que promove a decomposição dos carbonatos em ions $\mathrm{Ca}^{2+}, \mathrm{Mg}^{2+}$ e $\mathrm{HCO}_{3}^{-}$.

$\Delta$ reação do $\mathrm{CaCO}_{3}$ (ou do $\mathrm{MgCO}_{3}$ ) desenvolve-se em duas etapas, conforme citado en PIMENTEL (1966). Inicia1mente forma-.se äcido carbônico $\left(\mathrm{H}_{2} \mathrm{CO}_{3}\right)$ de acordo com a seguinte reação: $\mathrm{CO}_{2}(g)+\mathrm{H}_{2} \mathrm{O}(1)=\mathrm{H}_{2} \mathrm{CO}_{3}(\mathrm{aq})$ 
Quando o $\mathrm{CaCO}_{3}$ entra em contato com a ägua ë estabelecido o seguinte equilíbrio:

$$
\mathrm{CaCO}_{3}(\mathrm{~s}) \rightleftarrows \mathrm{Ca}^{2+}(\mathrm{aq})+\mathrm{CO}_{3}^{2-}(\mathrm{aq})
$$

A combinação das reações (1) e (2) mostra como o $\mathrm{CO}_{2}$ promove a solubilização do $\mathrm{CaCO}_{3}$ passando o íon carbonato $\left(\mathrm{CO}_{3}^{2-}\right)$ para a forma de bicarbonato $\left(\mathrm{HCO}_{3}\right)$ :

$$
\mathrm{H}_{2} \mathrm{CO}_{3}(\mathrm{aq})+\mathrm{CO}_{3}^{2-}(\mathrm{aq}) \rightleftarrows 2 \mathrm{HCO}_{3}(\mathrm{aq})
$$

A reação completa pode ser expressa assim:

$$
\begin{gathered}
\mathrm{CO}_{2}(\mathrm{~g})+\mathrm{H}_{2} \mathrm{O}(1)+\mathrm{CaCO}_{3}(\mathrm{~s}) \rightleftharpoons \mathrm{Ca}^{2}\left(\mathrm{HCO}_{3}\right)_{\mathrm{a}} \\
\longrightarrow \mathrm{Ca}^{2+}(\mathrm{aq})+2 \mathrm{HCO}_{3}^{-}(\mathrm{aq})
\end{gathered}
$$

Os íns $H+$ presentes na solução combinar-se-̃̃o comos $\mathrm{HCO}_{3}^{-}$, deixando $\mathrm{Ca}^{2+}$ livres para trocar $\operatorname{com~A1}{ }^{3+}$ e $\mathrm{H}^{+}$ presos às cargas negativas do solo.

$$
\begin{aligned}
& \mathrm{HCO}_{3}^{--}+\mathrm{H}^{+} \rightleftarrows \mathrm{H}_{2} \mathrm{CO}_{3} \rightleftarrows \mathrm{H}_{2} \mathrm{O}+\mathrm{CO}_{2} \\
& \mathrm{O}_{\mathrm{HCO}_{3}^{-}}^{-} \text {, porēm, ë um àcido fraco, e dissocia-se }
\end{aligned}
$$
apenas quando o pH do meio é elevado.

$$
\text { COLEMAN E THOMAS (1967) e MALAVOLTA (1967) }
$$

apresentam uma reação diferente para o carbonato de cālcio no solo: $\mathrm{CaCO}_{3}+\mathrm{H}_{2} \mathrm{O} \rightleftarrows \mathrm{Ca}^{2+}+\mathrm{HCO}_{3}^{-}+\mathrm{OH}^{-}$ 
Essa reação, na qual não ë considerada a participação do $\mathrm{CO}_{2}$, mostra a formação de íons $\mathrm{OH}^{-}$, responsāveis pela diminuição da acidez do solo. MALAvolta (1967) cita ainda, que a presença de $\mathrm{CO}_{2}$ pode diminuir a hidrölise indicada, diminuindo a alcalinidade.

A reação do calcärio como o solo è lenta e perdura por um período de alguns anos, THOMPSON e THOEH (1973) explicam que a taxa de reação ë mais räpida durante o primeiro e segundo ano, ate alcançar o valor mäximo de pH que resultarä da calagem. Depois a reação torna-se mais lenta e o pH diminue gradualmente. ANJos et alii (1981), aplicando calcário a um cambissol, encontraram elevação do pH ate atingir um mäximo ao redor de 6,5, dez meses apös a calagem. RAIJ et alii (1982) encontraram os maiores teores de Ca e Mg doze meses após a calagem.

Evidentemente a velocidade de reação varia com caracteristicas do solo e do calcärio. Um dos fatores que influem nessa reação é a acidez do solo. Se no solo houver grande quantidade de íons $\mathrm{H}^{+}$, estes, combinando-se com os íons $\mathrm{HCO}_{3}^{-}$, provocarão um deslocamento da reação (4); vista anteriormente, para a direita, aumentando a solubilização do carbonato de cälcio. Segundo COLEMAN e THOMAs (1967), quando a concentração de íons $\mathrm{H}^{+}$diminue, a solubilidade do carbonato ë redurida. Esse fato pode ser considerado como um dos responsáveis pela queda 
trou menor solubilidade do calcario no nível mals baixo de umidade, e, tambēm, menor solubilização a $10^{\circ} \mathrm{C}$ que a $30^{\circ} \mathrm{C}$.

Caracteristicas físicas e químicas do calcärio, como teor de carbonatos e grau de moagem, assim como também a textura da rocha que 1 he deu origem, afetam sua reação com o solo. MORGAN e SALTER (1923), estudando värias características dos calcärios como dureza, porosidade, composição cristalina e teor de cálcio e magnësio trocáveis, encontraram que essa ültima, ē a que tem maior efeito na reação do calcärio com o solo. O teor de carbonatos presentes determina o poder neutralizante (PN) de um calcärio expresso em equivalentes de $\mathrm{CaCO}_{3}$.

A proporção entre carbonato de cālcio e carbonato de magnésio também afeta a dissolução de calcārio. A dolomita $\left(\mathrm{MgCO}_{3}\right) \vec{E}$ menos solüvel do que a calcita e sua presença no calcärio determina uma diminuição de taxa de reação deste com o solo. GALLO e CATANI (1954) fizeram um estudo comparativo da solubilidade de alguns tipos de calcärio. Seus re- 
sultados mostraram solubilidade mais elevada para calcários com teores altos de cálcio em relação aos calcários dolomiticos. Esses autores verificaram tambēm que a textura da rocha calcária modifica a solubilidade: "calcärios com cristais macroscópicos nitidos são menos solüveis que calcärios com micro cristais".

Dentre os fatores envolvidos na reação do calcārio com o solo, a ärea superficial, que representa a superfície exposta à reação, é um dos mais intensamente estudados. Sua importância esta no fato de poder ser modificada mais facilmente que os outros fatores.

Com o decréscimo do tamanho da partícula, a superfície de reação aumenta. Assim, materiais mais finos reagem mais rapidamente com o solo. E combase nesse fato que a legislação brasileira exige que $100 \%$ de um calcärio passe em peneira no $10(2 \mathrm{~mm})$ e $50 \%$ em peneira no $50(0,297 \mathrm{~mm})$.

A distribuição do tamanho das particulas que compõem um calcārio não é suficiente para dar uma estimativa verdadeira da sua taxa de reação com o solo. Materiais com granulometrias iguais podem ter taxas de reaçäo diferentes. Muitos métodos para avaliar a eficiência de diferentes frações granulomëtricas e tipos de calcārio têm sido propostos, como por exemplo, a reação do calcário com ảcido acético, utilizado por GALLO (1954). THOMAS e GROSS (1952) fizeram uma comparação en- 
tre alguns desses métodos e indicaram o método proposto por BARNES (1947) como o melhor para avaliar a reação do calcário com o solo.

Grande parte dos autores, porëm, tem medido a reação direta do calcário com o solo para avaliar a sua eficiência. Isso é feito medindo-se as variações provocadas no pH e nos teorès de cālcio e magnésio trocáveis, como pode ser visto no trabalho de WUNSCHE e BOHNEN (1976).

Existem na 1 iteratura muitos trabalhos onde os autores aplicaram calcário com diferentes granulometrias ao solo e mediram as variações de pH, cälcio e magrésio trocáveis e produção de culturas, como os trabalhos de MEYER e VOLK (1952), ANDERSON (1969), CAMARGO (1972) e SOUZA e NEPTUNE; (1979). Concordando com o que é teoricamente esperado, esses autores encontraram que granulometrias mais finas reagem mais rapidamente com o solo, provocando maiores valores de pH.

Para o cảlculo da quantidade de calcärio que deve ser aplicada ao solo, para corrigir a acidez, considerase a eficiência das frações granulomêtricas que o compoẽm através da expressão PRNT (poder relativo de neutralização total). Cada fração granulomêtrica tem um peso de acordo com sua capacidade de reagir com o solo. Não existe, porém, uma expressão definitiva e vảlida para qualquer tipo de calcário e de solo. RATJ (1977) e BELLINGTERI (1978) apresentam expressöes dife- 
rentes para o cálculo do PRNT.

Com a preocupação de obter informações quantitativas sobre a taxa na qual o calcário reage com o solo, as reações entre tamanho da partícula e taxa de dissolução têm sido estudadas, do ponto de vista teórico pela hipótese da "equal reduction". Essa hipótese supõe que a taxa de perda de massa é diretamente proporcional à área exposta à reação num determinado instante. A espessura do diâmetro que é reduzida, em cada partícula não varia com o tamanho desta pois a disso1 ução se dá pela remoção de uma camada de espessura uniforme.

$$
\text { o desenvolvimento matemático dessa hipōtese }
$$

tem encontrado relação com o que ocorre no solo, como pode ser visto em SCHOLENBERG e SALTER (1943) e SWARTZENDRUBER e BARBER (1965).

A velocidade com a qual. o calcário promove a neutralização do solo depende, ainda, da diłusão dos íons $\mathrm{Ca}^{+2}$ $\mathrm{Mg}^{+2}$ e $\mathrm{HCO}_{3}^{-}$pelo volume de terra. A difusão do cảlcio é 1 enta e é por isso que, de acordo com BARBER (1967), calcário finamente moído e uniformemente misturado com o solo, neutraliza a acidez mais rapidamente. Existem mais partículas por unidade de volume de solo, e a distância entre partículas é menor, aumentando a ärea de ação total.

São necessários, aỉnda, estudos para conhecer-se, completamente, a solubilização do calcário no solo e os 
fatores do solo e do próprio material que têm influência nessa reação. Um fator do solo a ser incluido entre os que podem acelerar a reação do calcārio ê a presença de matéria orgânica. BELLINGIERI ( 1983 ), aplicando diferentes frações granulométricas à três tipos de solo, encontrou que frações mais grosseiras reagiram apenas no solo que continha maior teor de matéria orgânica. Esse fato, segundo o autor, poderia estar re1 acionado com uma maior quantidade de äcidos oriundos da mineralização da matëria orgânica nesse solo.

A presença de maior quantidade de matéria orgânica em decomposição, como no caso de incorporação de adubo verde ou restos de cultura ao solo, poderia aumentar a solubilização de partículas mais grosseiras de calcärio ou aumentar a eficiência dessas fraçöes.

\subsection{DECOMPOSIÇÃO DA MATERIA ORGÂNICA}

Quando resíduos orgânicos são aplicados ao so1o, inicia-se, imediatamente, a decomposição desse material pelos microrganismos presentes. Esse processoé, em geral, räpido no início, diminuindo gradualmente atë atíngir um valor mínimo constante.

A rapidez coin que o substrato è oxidado depende de sua composição química e das condições do meio,tais como temperatura, oxigênio $\left(\mathrm{O}_{2}\right)$, umidade, $\mathrm{pH}$ e nutrientes disponiveis. 
A exposição que se segue visa mostrar, inicialmente, como é feita a determinação da taxa de decomposição da matéria orgânica e, em seguida, como os diversos fatores do material e do meio afetam essa taxa.

\subsubsection{Medida de taxa e extensão da decomposição}

Muitos métodos tem sido utilizados para determinar taxas de decomposição da matéria orgânica no solo. Esses métodos baseiam-se no aparecimento de produtos da decomposição, no desaparecimento de algum componente específico ou na diminuição do pröprio teor de matéria orgânica.

Durante a degradação do material orgânico,grande parte do carbono é liberada na forma de $\mathrm{CO}_{2}$ pela respiração dos microrganismos, de maneira que o $\mathrm{CO}_{2}$ torna-se um dos principais produtos dessa decomposição. ALISSON (1973) cita que o processo de decomposição converte em $\mathrm{CO}_{2} 60 \%$ ou mais do carbono adicionado ao solo. Assim, segundo consideram diversos autores, como WAKSMAN (1952), RUSSELL e RUSSELL (1964) e WAGNER (1975), o $\mathrm{CO}_{2}$ pode ser utilizado para medir a taxa e extensão da decomposição e avaliar a atividade microbiana. A liberação de $\mathrm{CO}_{2}$ do solo é denominada, por alguns autores, de respiração ou mais comumente de evolução do $\mathrm{CO}_{2}$ do soló.

Deve-se observar, porëm, algumas restrições à medida da evolução do $\mathrm{CO}_{2}$ na avaliação da atividade microbiana. 
Ainda que a atividade de microrganismos heterotróficos resulte em liberação de $\mathrm{CO}_{2}$ no solo, existem outros microrganismos que não produzem $\mathrm{CO}_{2}$ mas estão em atividade. CORBET (1935) comenta que nem sempre a evolução do $\mathrm{CO}_{2} \vec{e}$ proporcional ao nümero de microrganismos.

Por outro lado, a evolução do $\mathrm{CO}_{2}$ "do solo não é decorrente apenas da decomposição da matēria orgânica e da atividade microbiana. BECKMANN e SCHARPENSEEL (1964) verificaram que o $\mathrm{CO}_{2}$ pode ser 1 iberado por descarboxilação química. Essa reação começa com pH 6,5 a 7,0 e sua taxa e extensão aumentam com a elevação do pH. Segundo esses autores, o aumento da respiração do solo, que se segue à calagem, pode estar associado a esse processo.

Devido a esses fatores, torna-se difícil comparar medidas isoladas de evolução do $\mathrm{CO}_{2}$. Em estudos comparativos, porém, essa medida é utilizada com frequência, e tem apresentado bons resultados em estudos da decomposição de resíduos orgânicos.

\subsubsection{Fatores que afetam a decomposição}

Temperatura, grau de umidade, aeração, pH e a relação C/N são alguns dos fatores que exercem influência sobre os microrganismos e sobre a decomposição da matéria orgânica no solo. 


\section{2 .2 .1$. Temperatura}

A faixa de temperatura ótima para a decomposição da matéria orgânica estä entre $30^{\circ} \mathrm{C}$ e $40^{\circ} \mathrm{C}$. ABRASIMOVA (1979) encontrou um aumento na produção de $\mathrm{CO}_{2}$ durante a decomposição da matéria orgânica com o aumento da temperatura de $15^{\circ} \mathrm{C}$ a $35^{\circ} \mathrm{C}$. Segundo os värios autores que têm tratado do assunto, o processo de decomposição não se modifica.Assim, a qualquer temperatura, as reações e os produtos são os mesmos, ocorrendo modificação apenas nas taxas de quebra do tecido orgânico e evolução do $\mathrm{CO}_{2}$.

\subsubsection{Grau de umidade e aeração}

Alterações marcantes no processo de decomposição são causadas por variações no teor de água, porque esta modifica a movimentação do ar e o suprimento de oxigênio no solo. Quando hả pouca aeração, falta oxigênio e a decomposição é lenta; os microrganismos fazem respiraçãofermentativa, liberando no meio mais álcoois e äcidos orgânicos do que se a respiração fosse aeróbica. Em condições hidromórficas, pela falta de oxigênio, não hā, por exemplo, nitrificação, e o nitrogênio permanece na forma de amônia.

A àgua, entretanto, é primordial para a vida, e em solos secos há pouca atividade biológica. MILLER e JOHNSON 
(1964) incubaram solos com diferentes teores de ägua por 14 dias e observaram um aumento na produção de $\mathrm{CO}_{2}$ a partir de um valor mínimo, quando o solo estava seco ao ar, a um valor máximo com a água numa tensão de 0,15 bars. Mas a produção de $\mathrm{CO}_{2}$ diminuiu quando o grau de umidade foi maior que esse valor, indicando deficiência na aeração. o efeito do teor de āgua sobre a mineralização da matēria orgânica também pode ser visto em ALMEIDA (1983), que incubou solos com vinhaça por três meses a 40,60 e $80 \%$ da capacidade de retenção de ägua e encontrou mineralização mais rápida no solo mais seco. Em cada solo existe um grau ideal de umidade que permite, ao mesmo tempo, um suprimento adequado de āgua e de oxigênio, para uma rāpida e completa decomposição da matéria orgânica.

\section{$2.2 \cdot 2 \cdot 3 \cdot \mathrm{pH}$}

Os microrganismos possuem uma faixa ideal de pH para seu desenvolvimento. Existem microrganismos acidófilos que vivem em $\mathrm{pH}$ até 2,0 , e microrganismos basófilos que vivem em $p H$ maior do que 8,0. A maior parte dos microrganismos, porëm, se desenvolve melhor em $\mathrm{pH}$ entre 4,0 e 7,0.De maneira geral, no solo, predominam fungos em $\mathrm{pH}^{\mathrm{a}} \mathrm{cido}$ e bactérias em pH ligeiramente àcido ou ligeiramente alcalino. Processos realizados por um determinado grupo de microrganismos tambēm têm uma faixa ōtima de pH na qual a velocidade do processo é maior. 
Valores de pH 1 igeiramente äcidos ou neutros parecem favorecer a decomposição. E o que mostra, o trabalho de DYAL et alii (1939). Esses autores incubaram resíduos de gramíneas em solos com diferentes valores de pH e encontraram decomposição mais räpida em solos compH entre 5,9 e 7,0 do que em solos com pH entre 3,7 e 4,5. Esses resultados são semelhantes aos citados por MAYAUDON (1967).

A calagem de solos àcidos é um fator de aumento na mineralização do carbono orgânico do solo, como apontaram McLean et alii (1967). A atividade microbiana é estimulada pelo aumento de $\mathrm{pH}$ e fornecimento dos íons cálcio e magnésio.

0 pH do solo interfere na decomposição da matéria orgânica não só pelo efeito direto sobre os microrganismos, mas também por afetar a disponibilidade de nutrientes e a solubilidade de íons tóxicos.

\section{$2.2 .2 \cdot 4 . \underline{R e} 1$ a ção $C / N$}

E de conhecimento geral que a relação entre o conteūdo de carbono e o conteūdo de nitrogênio, ou seja a re1 ação C/N do material, controla a taxa de decomposição. Isto porque os microrganismos precisam de uma proporção definida de carbono e nitrogênio para multiplicação e crescimento. Assim, se o material orgânico contiver muito carbono, em relação ao nitrogênio, a degradação serä lenta pois não haverā ni- 
trogênio suficiente para o cresciménto microbiano. Por outro lado, se a relação $C / N$ for baixa haverá sobra de nitrogênio, que è liberado no solo na forma de amônio.

A medida que se processa a decomposição, a relação C/N do material diminui porque o carbono é perdido como $\mathrm{CO}_{2}$, enquanto que o nitrogênio é conservado. ALISSON. (1973) cita que as plantas em geral tem $40 \%$ a $45 \%$ de carbono, e por esta razão plantas com mais de $1,5 \%$ a $1,7 \%$ de nitrogênio 1 iberam grande parte desse elemento na forma de amônio; mas, se o teor de nitrogênio for menor que $1,5 \%$ muito pouco amônio é liberado .

Em um estudo feito por Albuquerque (1976) e AQUINO (1976), sobre a decomposição da matéria orgânica em solos argilosos e arenosos, mostrou-se que a adição de nitrogênio à palha de milho diminuiu o teor de matéria orgânica ao final de 30 dias, indicando maior decomposição. Como palha de milho tem alta relação $\mathrm{C} / \mathrm{N}$, a adição de nitrogênio acelerou o processo de degradação.

A relação C/N não é, porëm, o ünico fator do material orgânico determinante da taxa de decomposição. o teor de constituintes como celulose, hemicelulose e lignina, tambẻm è importante. DYAL et alii (1939) verificaram que plantas com altos teores desses constituintes tiveram decomposição mais lenta do que plantas contendo menores teores. Segundo FASSBENDER 
(1984) a relação lignina/celulose também controla a mineralizaçao. A lignina, devido a sua constituição química, è um dos compostos de mais difícil decomposição numa planta.

E importante, para o desenvolvimento dos microrganismos, a presença de nutrientes inorgânicos, tanto no solo como no material em decomposição. WAKSMAN e TENNEY (1928) mostraram que, com a maturação da planta, ocorre um desequilíbrio entre os carbohidratos e os minerais requeridos pelos microrganismos, diminuindo a velocidade de decomposição da matēria orgânica.

Em suma, pode-se dizer que, entre os fatores que afetam a decomposição, o suprimento de oxigênio, o pH e a relação $C / N$ são os que influem mais intensamenté na seleção dos processos predominantes.

A matéria orgânica e os produtos de decomposição provocam alterações físicas e químicas no solo e, entre essas destaca-se, neste trabalho, a influência sobre o pH e sobre a solubilização de minerais.

2.3. INFLUENCIA DA MATERIA ORGÂNICA SOBRE O pH DO SOLO

Quando uma certa quantidade de matēria orgânica é aplicada ao solo, ocorrem alterações em alguns atributos do solo, dentre eles o pH. Segundo WUTKE (1972), a matéria orgânica aplicada ao solo provoca um abaixamento do pH porque 
hä um aumento da CTC do complexo coloidal, e como, normalmente, a matēria orgânica não tem íons bāsicos suficientes para contrabalançar esse aumento de CTC, o grau de saturação de bases diminui e o pH assume valores mais baixos.

Alguns autores, porém, como EIRA e CARVALHO (1970), FERRAZ (1978) e NEVES et alii (1983), têm relatado que determinados tipos de materiais aplicados ao solo provocam elevação do pH: ocorre que o efeito da matéria orgânica sobre o pH pode ser decorrente da atividade microbiana durante a decomposição desse material.

Os produtos do metabolismo microbiano, de acordo com DOMMERGUES e MANGENOT (1970) podem ser alcalinizantes, (como a amônia) ou acidificantes (como ácidos minerais ou orgânicos). A concentração de äcidos orgânicos no solo é, em geral, baixa e bastante variável. Entretanto, altas concentrações podem ser obtidas em zonas localizadas, onde a atividade biológica é intensa, como por exemplo perto de resíduos em decomposição, provocando abaixamento do pH. A acidificação pode dar-se, também, pela produção de $\mathrm{CO}_{2}$ que forma ácido carbônico na solução.

0 aumento de $\mathrm{pH}$, que ocorre devido à adição de matéria orgânica, tem sido atribuido à liberação de amônio no solo, jā que materiais como glicose, que não contém nitrogênio, provocam um abaixamento do pH, como foi encontrado por EIRA e CARVALHO (1970). 
Outra explicação para o aumento do $\mathrm{pH}$ é "dada por ROSATO (1978). Esse autor incubou solos com torta de algodão e econtrou aumento de pH, mas nenhuma alteração nos teores de $\mathrm{Al}^{3+}$ trocável e $\mathrm{H}$ total. Sugeriu, então, que radicais orgânicos com cargas negativas formados durante a decomposição, reteriam os íons $\mathrm{H}^{+}$da solução, elevando, consequen temente, o pH. Costa (1983) encontrou, porém, uma diminuição do $A 1^{3+}$ trocável pela aplicação de matéria orgânica ao solo. Esse fato pode ter ocorrido, segundo o autor, pela complexação desses íons por compostos orgânicos.

Observa-se do exposto que os resultados apresentados por diversos autores são conflitantes. Não se pode perceber, a partir dos dados fornecidos, uma explicação para essas discrèpâncias. Mas pode-se dizer que o aumento do pH, causado pela matéria orgânica, estaria, pelo menos em parte, relacionado com retenção ou complexação de íons que causam a acidez .

2.4. ATIVIDADE MICROBIANA E SOLUBILIZAÇÃO DE MINERAIS.

Existem diversos trabalhos relatando: que a dissolução no solo de formas pouco solúveis de fosfato é estimulada pela atividade microbiana.

O aumento da solubilidade de fosfatos pode ser observado pela absorção desse elemento pelas plantas. GERRETSEN 
(1948) encontrou que a quantidade de fósforo assimilada pelas plantas foi maior em condições não estéreis que em condições de esterilidade, mostrando que os microrganismos tornam disponíveis quantidades de fósforo que eram inacessíveis às plantas.

A adição de matéria orgânica ao solo aumenta a dissolução de fosfatos dicálcicos, como foi encontrado por SREERAMUCU e PRATT (1970). A ação de ácidos, produzidos pelos microrganismos durante a decomposição, torna os fosfatos mais solúveis. SWABY e SHERBER (1958) e STEVENSON (1967) já haviam citado, anteriormente, que os ácidos lático, cítrico, glicolítico, succínico, fórmico e acético, produzidos pormicrorganismos, solubilizam fosfatos. Acidos que foram complexos estáveis com os íons cālcio, ferro, magnésio e alumínio, como o 2 - ceto-glucônico, também são importantes na solubi1 ização, como demostrado por DUFF et alii (1963).

Ácidos inorgânicos, produzidos na decomposição da matéria orgânica, também podem agir sobre os fosfatos. HAYMAN (1975) cita que o dióxido de carbono, ao provocar diminuição de pH ao redor do fosfato, aumentaria sua solubili$z$ ação. A produção biológica de ácidos inorgânicos, como o sulfúrico e o nítrico, pode afetar a solubilização nãosó do fósforo como também de cālcio, magnésio e alumínio. A ativi.dade nitrificante nos solos é apontada por ALEXANDER (1961) 
como importante na solubilização de minerais. o efeito da aplicação de matéria orgânica ao solo, sobre a liberação de formas não disponíveis de fósforo, pode ser vista em CARVALHO et alii (1977) e ASSUMPÇÃO (1981).

Da mesma forma como atuam sobre a solubilização de fosfatos, os microrganismos podem agir sobre carbonatos de cálcio e magnêsio. A ação microbiana sobre carbonatos foi observada por LOUW e WEBLEY (1979). Esses autores verificaram que microrganismos isolados da rizosfera, produziam halos em torno de suas colônias em placas de incubação contendo carbonato de cálcio, indicando solubilização. o exame da natureza dos àcidos orgânicos produzidos mostrou que os microrganismos 1 iberaram principalmente ácido lático.

Os microrganismos podem atuar sobre os carbonatos pela liberação de $\mathrm{CO}_{2}$ e formação de ảcido carbônico. BEAR (1963) cita, como exemplo clássico, o efeito corrosivo do anidrido carbônico, expelido por raízes de plantas, sobre uma placa de mármore.

Durante intensa atividade biolögica é observado um teor mais alto de $\mathrm{CO}_{2}$ no ar do solo. RUSSELL e RUSSELL (1964) mencionam que o uso de adubo verde, espécialmente se as plantas são muito suculentas, aumentará a quantidade de $\mathrm{CO}_{2}$ do ar do solo, podendo até mesmo inibir a germinação. 0 aumento da concentração de $\mathrm{CO}_{2}$ do ar, segundo KHEGAY et alii 
(1981), leva a um aumento na concentração de íons bicarbonato na solução do solo, aumentando, assim, a solubilidade de carbonatos pouco solúveis.

Mudanças na concentração hidrogeniônica do meio causadas por microrganismos, contribuem tanto para a formaça quanto para a solubilização de carbonatos de cálcio e magnésio. STANIER et alii (1969) citam que processos que aumentam a alcalinidade do meio, como a redução do sulfato e a denitrificação que ocorrem nos oceanos, favorecem a deposíção de $\mathrm{CaCO}_{3}$, enquanto que a produção de äcidos orgânicos no solo favorece a solubilização de depósitos calcários.

\subsection{CONSIDERAÇÕES FINAIS}

Diate das observações aqui registradas pode-se dizer que há apoio experimental e científico para as hipóteses formuladas para este trabalho. Os trabalhos relatados mostram que é de se supor que a máteria orgânica tenha influência na solubilização do calcário. 


\section{MATERIAIS E METODOS}

\subsection{MATERIAIS}

Para verificar o efeito da matéria orgânica em decomposição sobre a solubilização do calcārio, aplicou-se a um solo com calcärio quatro resíduos orgânicos de uso comum na agricultura.

\section{$3 \cdot 1 \cdot 1$. So10}

o solo usado no experimento foi o horizonte Ap de uma Terra Roxa Estruturada, textura barro argilosa, classificada como série "Luiz de Queiroz" por RANZANI et alii (1966) de ocorrência nas proximidades do Posto Meteorológico da ESALQ. Sua anälise química foi realizada de acordo con os métodos de anālise de rotina, com excessão do teor de carbono orgânico, e é apresentada no QUADRO 1. O carbono orgânico foi determinado por via seca em um, aparelho … Wosthoff Carmhograph $12 \mathrm{~A}$. 
QUADRo 1: Anālise química do solo Terra Roxa Estruturada série "Luiz de Queiroz".

\begin{tabular}{|c|c|c|c|c|c|c|c|c|}
\hline \multirow{2}{*}{$\mathrm{pH}$} & \multirow{2}{*}{$\% \mathrm{C}$} & \multicolumn{2}{|c|}{ Teor de rons } & \multicolumn{2}{|c|}{ trocāveis } & (meq/100 & \multirow{2}{*}{\multicolumn{2}{|c|}{$\frac{\mathrm{solo})}{\mathrm{H}^{+}}$}} \\
\hline & & $\mathrm{PO}_{4}^{3-}$ & $\mathrm{K}^{+}$ & $\mathrm{Ca}^{2+}$ & $\mathrm{Mg}^{2+}$ & $\mathrm{Al}^{3+}$ & & \\
\hline 5,3 & 2,43 & 0,13 & 0,49 & 3,08 & 1,16 & 0,26 & & 4,24 \\
\hline
\end{tabular}

Para a incubação uma amostra do solo foi seca ao ar e passada em peneira $2 \mathrm{~mm}$.

\subsubsection{Calcário}

As anālises química e granulométrica do calcā-rio, feitas também segundo os métodos de rotina, encontram- se no QUADRO 2. Trata-se de um calcário agrícola da região de Piracicaba e pode ser classificado como dolomito-calcítico pelos seus teores de cālcio e magnésio, de acordo com ABRAHÃo (1983). 
QUADRO 2: Anālise química e granulométrica do calcário.

\begin{tabular}{|c|c|c|c|c|}
\hline \multirow{3}{*}{ P RNT } & \multicolumn{2}{|c|}{ Granulometria } & Câlcio & Magnēsio \\
\hline & Peneira & Peneira & & \\
\hline & 10 & 50 & $\% \mathrm{CaO} \% \mathrm{CaCO}_{3}$ & $\% \mathrm{MgO} \%^{\mathrm{MgCO}_{3}}$ \\
\hline 58,15 & 97,80 & 50,72 & 23,8 & 16,5 \\
\hline
\end{tabular}

3.1.3. Material orgânico

Para a escolha do tipo de matêria orgânica a ser aplicada ao solo, foram considerados como critérios os seguintes atributos: relação $\mathrm{C} / \mathrm{N}$, composição química e facilidade de decomposição. Com base nesses critérios, foram esco1hidos materiais que tivessem comportamento diferente durante sua degradação no solo. Os materiais utilizados foram os seguintes: soja, composto, "palha de milho e bagaço de cana.

o material soja (S) corresponde à parte aérea da planta cortada a cinco centímetros do solo. Esse material foi colhido à ëpoca do florescimento e sua incorporação ao so1o corresponde à utilização de um adubo verde. O composto (C) foi obtido de cama de bezerreiro que, no caso, era um material 
contendo esterco e feno misturados e parcialmente decompostos. A palha de milho (M) compõe-se das folhas secas no campo após a colheita. E, por fim, o bagaço de cana (B) é constituído de colmos da cana depois de passados em moinho para retirar o caldo.

os teores de carbono e nitrogênio desses materiais e suas respectivas relações C/N são apresentadas no QUADRO 3. O carbono foi determinado por via seca (ver ítem 3.1.1) e o nitrogênio pelo método de Kjeldahl, utilizando microdestilador.

QUADRo 3: Teores de Carbono (\%) e Nitrogênio (\%) e C/N dos materiais orgânicos aplicados.

\begin{tabular}{lccl}
\hline MATERIAL & C\% & N\% & C/N \\
\hline Soja & 42,6 & 1,97 & 21,6 \\
Composto & 33,7 & 1,62 & 22,0 \\
Palha de Milho & 39,4 & 0,75 & 52,5 \\
Bagaço de Cana & 42,6 & 1,56 & 27.3 \\
\hline
\end{tabular}

os quatro materiais foram secados em estufa a $40^{\circ} \mathrm{C}$, triturados em moinho (Wiley Mill Standard 3) e individualmente peneirados em tamizes com crivo de $1 \mathrm{~mm}$ de abertura. Utilizou-se para a montagem dos tratamentos o material menor do que $1 \mathrm{~mm}$. 
3.2. METODOS

Em se tratando de uma dissertação científica, optou-se por apresentar separadamente, para maior clareza, os métodos empregados para a condução deste trabalho.

\subsubsection{Método experimental}

As hipóteses de trabalho foram formuladas a partir das observações feitas principalmente através do exame de parte da 1 iteratura disponível sobre o assunto. As : hipóteses foram consideradas como base para a eleição do delineamento experimental e do tratamento estatístico para anảise e interpretação dos resultados.

o delineamento experimental para testar as relações causa-efeito expressas pelas hipóteses formuladas baseou-se nos métodos gerais segundo Mill, citado por RESCHER (1964), que são, respectivamente, o Método da Concordância e o Método da Variação Concomitante.

\subsubsection{Método operacional}

o experimento constou da aplicação de dez tratamentos assim discriminados: soja, composto, palha de milho, e bagaço de cana (ver 3.1.3.) nas dosagens de $5 \%$ e $10 \%$, res- 
pectivamente, com um tratamento testemunha, correspondendo a uma dose $0 \%$ de matéria orgânica, e um tratamento esterilizado. Cada tratamento foi repetido três vezes. A duração da incubação foi de 12 semanas, sendo que a cada semana eram retiradas amostras para anālise. Os detalhes reférentes à incubação e $\grave{a}$ amostragem serão apresentadas adiante.

\subsubsection{Determinação da dose de calcário}

Para determinar a dose de calcário a ser aplicada ao solo, utilizou-se o método que considera a correlação entre pH e saturação de bases do solo (V\%). Escolheu-se a elevação de V\% para $90 \%$ de forma a atingir um valor de pH maior do que 6,5. Para os cālculos utilizou-se a equação recomendada por QUAGGIO (1983).

$$
N C=\frac{T\left(V_{2}-V_{1}\right)}{100} \cdot f
$$

Onde:

$$
\begin{aligned}
\mathrm{NC}= & \text { Quantidade de calcārio a ser aplicada } \\
& \left(\text { meq/100 } \mathrm{cm}^{3}\right) \\
\mathrm{T}= & \text { Capacidade de troca de cātions (meq/100 } \mathrm{cm}^{3} \text { ) } \\
\mathrm{V}_{1}= & \text { Saturação de bases atual }(\%) \\
\mathrm{V}_{2}= & \text { Saturação de bases desejada (\%) } \\
\mathrm{f}= & \text { Fator de calagem }=\frac{100}{\text { PRNT }}
\end{aligned}
$$


A partir dos dados apresentados no QUADRO 1 , calculou-se os valores de $T\left(9,32 \mathrm{meq} / 100 \mathrm{~cm}^{3}\right)$ e $v_{1}(50,75 \%)$. 0 valor calculado para NC foi de 6,29 meq $\mathrm{CaCO}_{3} / 100 \mathrm{~cm}^{3}$ de so1o. Sabendo-se que a densidade da terra dentro dos frascos de incubação ficaria em torno de $1,1 \mathrm{~g} / \mathrm{cm}^{3}$ determinou-se a quantidade de calcārio, em peso, a ser adicionada à terra.

Embora hajam restrições a essa maneira de se analisar a composição volumétrica do solo utilizando amostras deformadas, a metodologia foi seguida porque considerou-se que a investigação proposta neste trabalho deveria ser conduzida seguindo os procedimentos em uso.

3.2.2.2. Determinação do teor de ägua para incubação.

o solo foi incubado com um teor de àgua correspondente à capacidade de campo, para permitir um fornecimento adequado de ar e ägua. Para determinação. desse teor de àgua, utilizou-se o mẻtodo denominado TSFM (torrão separado pela frente de molhamento).

Esse método considera que o teor de ägua do torrão úmido que se separa da terra pela frente de molhamento pode ser explicado pelos mesmos princípios que explicam o teor de àgua de um solo em capacidade de campo. 
A metodologia relatada em costa (1983) foi 1igeiramente modificada. Nesse trabalho adicionou-se 5 m 1 de āgua à terra e esperou-se 120 segundos para separar o torrão úmido.

Os teores de umidade determinados para cada tratamento estão no QUADRO 4.

QUADRo 4: Teores de ägua (\% de peso sêco) que foram utilizados na incubação em cada tratamento.

\begin{tabular}{|c|c|c|c|c|c|c|c|c|}
\hline TRAT & TRAT & $\mathrm{S}$ & TRAT & C & TRA & M & TRAT & $B$ \\
\hline TEST & $5 \%$ & $10 \%$ & $5 \%$ & $10 \%$ & $5 \%$ & $10 \%$ & $5 \%$ & $10 \%$ \\
\hline 24,8 & 32,3 & 37,6 & 32,1 & 36,5 & 32,7 & 39,1 & 34,6 & 41,8 \\
\hline
\end{tabular}

\subsubsection{Montagem dos tratamentos.}

A terra misturada ao calcārio e à matéria orgânica foi incubada em frascos de vidro com capacidade de $100 \mathrm{ml}$. Cada frasco recebeu $40 \mathrm{~g}$ de terra mais a quantidade correspondente de calcārio e matéria orgânica. Cada frasco representou uma repetição de um tratamento e de um período de tempo, perfazendo um total de 360 frascos, ou seja, 10 tratamentos $x$ repetições $x 12$ semanas de incubação. 
Depois de colocada a ägua no teor calculado, os frascos foram cobertos com papel de alumínio e incubados em condições de laboratōrio. 0 papel de alumínio teve a função de diminuir as perdas de ägua, deixando, porëm, que houvesse restrita troca de ar por difusão. o teor de ägua em cada um dos frascos foi mantido constante. A quantidade de āgua a ser colocada foi controlada por diferença de peso.

A terra foi colocada nos frascos com auxílio de um funil para conseguir uma distribuição uniforme das partícu1 as .

o tratamento esterilizado foi montado da mesma maneira que os outros tratamentos. A esterilização foi feita com clorofórmio $\left(\mathrm{CHCl}_{3}\right)$ conforme o método descrito por JENKINSON (1966). Os frascos contendo solo, calcário e a quantidade de água determinada anteriormente foram colocados em dessecadores, juntamente com um becker contendo cerca de $30 \mathrm{ml} \mathrm{de} \mathrm{CHCl}_{3}$. Os dessecadores foram ligados a uma bomba de vācuo até o clorofórmio começar a ferver. Todas as semanas um dos dessecadores era aberto para a retirada de três frascos e em seguida era fechado e 1 igado ao vảcuo novamente. Não foi feita reposição de ăgua porque as amostras retiradas mostraram que a perda foi desprezíve 1 .

De cada frasco, retirava-se uma amostra de solo, de aproximadamente $10 \mathrm{~g}$ para medir a evolução de $\mathrm{CO}_{2}$. 0 res- 
tante era seco em estufa a $40^{\circ} \mathrm{C}$ por 48 horas e usado nas ana1 ises realizadas.

Foi determinada a evolução de $\mathrm{CO}_{2}$ para avaliação da decomposição da matéria orgânica e da quantidade de $\mathrm{CO}_{2}$ no meio, e mediu-se pH e cālcio e magnēsio trocáveis para avaliar a solubilização do calcārio.

As temperaturas mäxima e mínima diārias no 1 aboratório durante as 12 semanas estão registradas no QUADRO 5 .

QUADRo 5: Valores de temperatura $\left({ }^{\circ} \mathrm{C}\right)$ mäxima (M) e mínima (m) diäria e média semanal registrados durante o experimento.

\begin{tabular}{|c|c|c|c|c|c|c|c|c|c|}
\hline \multirow[b]{2}{*}{ SEMANA } & \multirow[b]{2}{*}{ TERIPEATURA } & \multicolumn{7}{|c|}{ DIA DA SEMLANA } & \multirow{2}{*}{$\begin{array}{c}\text { MEDIA } \\
\text { SEMANAL }\end{array}$} \\
\hline & & SEG & TER & QUN & QUI & SEX & SAB & $\mathrm{DOM}$ & \\
\hline$I$ & $\begin{array}{l}M \\
m\end{array}$ & $\begin{array}{l}29 \\
29\end{array}$ & $\begin{array}{l}29 \\
29\end{array}$ & $\begin{array}{l}29 \\
29\end{array}$ & $\begin{array}{l}29 \\
28\end{array}$ & $\begin{array}{l}30 \\
29\end{array}$ & $\begin{array}{l}30 \\
29\end{array}$ & $\begin{array}{l}30 \\
30\end{array}$ & 29,2 \\
\hline I I & $M$ & $\begin{array}{l}31 \\
29\end{array}$ & $\begin{array}{l}31 \\
29\end{array}$ & $\begin{array}{l}30 \\
29\end{array}$ & $\begin{array}{l}30 \\
29\end{array}$ & $\begin{array}{l}31 \\
29\end{array}$ & $\begin{array}{l}31 \\
29\end{array}$ & $\begin{array}{l}31 \\
29\end{array}$ & 29,9 \\
\hline I I I & $\begin{array}{l}M \\
m\end{array}$ & $\begin{array}{l}31 \\
29\end{array}$ & $\begin{array}{l}31 \\
29\end{array}$ & $\begin{array}{l}30 \\
29\end{array}$ & $\begin{array}{l}30 \\
29\end{array}$ & $\begin{array}{l}30 \\
28\end{array}$ & $\begin{array}{l}30 \\
28\end{array}$ & $\begin{array}{l}29 \\
28\end{array}$ & 29,4 \\
\hline IV & $\begin{array}{l}M \\
\text { m }\end{array}$ & $\begin{array}{l}29 \\
28\end{array}$ & $\begin{array}{l}30 \\
28\end{array}$ & $\begin{array}{l}28 \\
28\end{array}$ & $\begin{array}{l}29 \\
28\end{array}$ & $\begin{array}{l}28 \\
27\end{array}$ & $\begin{array}{l}29 \\
27\end{array}$ & $\begin{array}{l}30 \\
26\end{array}$ & 28,2 \\
\hline $\mathbf{v}$ & $\begin{array}{l}M \\
\text { m }\end{array}$ & $\begin{array}{l}30 \\
26\end{array}$ & $\begin{array}{l}27 \\
25\end{array}$ & $\begin{array}{l}27 \\
26\end{array}$ & $\begin{array}{l}27 \\
25\end{array}$ & $\begin{array}{l}26 \\
24\end{array}$ & $\begin{array}{l}27 \\
25\end{array}$ & $\begin{array}{l}28 \\
25\end{array}$ & 26,3 \\
\hline VI & $\begin{array}{l}M \\
\mathrm{~m}\end{array}$ & $\begin{array}{l}26 \\
25\end{array}$ & $\begin{array}{l}26 \\
25\end{array}$ & $\begin{array}{l}27 \\
25\end{array}$ & $\begin{array}{l}27 \\
26\end{array}$ & $\begin{array}{l}28 \\
26\end{array}$ & $\begin{array}{l}28 \\
26\end{array}$ & $\begin{array}{l}28 \\
27\end{array}$ & 26,4 \\
\hline VI I & $\begin{array}{l}M \\
\text { m }\end{array}$ & $\begin{array}{l}28 \\
27\end{array}$ & $\begin{array}{l}28 \\
26\end{array}$ & $\begin{array}{l}26 \\
25\end{array}$ & $\begin{array}{l}26 \\
24\end{array}$ & $\begin{array}{l}25 \\
23\end{array}$ & $\begin{array}{l}25 \\
23\end{array}$ & $\begin{array}{l}25 \\
24\end{array}$ & 25,4 \\
\hline VIII & $\begin{array}{l}\text { M } \\
\text { m }\end{array}$ & $\begin{array}{l}26 \\
21\end{array}$ & $\begin{array}{r}27 \\
25\end{array}$ & $\begin{array}{l}26 \\
25\end{array}$ & $\begin{array}{l}26 \\
24\end{array}$ & $\begin{array}{l}25 \\
24\end{array}$ & $\begin{array}{l}25 \\
23\end{array}$ & $\begin{array}{l}24 \\
23\end{array}$ & 24,6 \\
\hline IX & M & $\begin{array}{l}24 \\
22\end{array}$ & $\begin{array}{l}25 \\
22\end{array}$ & $\begin{array}{l}25 \\
24\end{array}$ & $\begin{array}{l}25 \\
24\end{array}$ & $\begin{array}{l}26 \\
25\end{array}$ & $\begin{array}{l}26 \\
25\end{array}$ & $\begin{array}{r}26 \\
.25\end{array}$ & 24,6 \\
\hline $\mathrm{x}$ & $\begin{array}{l}M \\
\text { m }\end{array}$ & $\begin{array}{l}26 \\
24\end{array}$ & $\begin{array}{l}26 \\
26\end{array}$ & $\begin{array}{l}26 \\
25\end{array}$ & $\begin{array}{l}26 \\
25\end{array}$ & $\begin{array}{l}27 \\
25\end{array}$ & $\begin{array}{l}27 \\
25\end{array}$ & $\begin{array}{l}27 \\
25\end{array}$ & 25,7 \\
\hline$x I$ & $\begin{array}{l}M \\
m\end{array}$ & $\begin{array}{l}26 \\
24\end{array}$ & $\begin{array}{l}26 \\
24\end{array}$ & $\begin{array}{l}26 \\
25\end{array}$ & $\begin{array}{l}25 \\
25\end{array}$ & $\begin{array}{l}25 \\
24\end{array}$ & $\begin{array}{l}25 \\
24\end{array}$ & $\begin{array}{l}24 \\
23\end{array}$ & 24,7 \\
\hline$X I I$ & $\begin{array}{l}M \\
\text { m }\end{array}$ & $\begin{array}{l}24 \\
22\end{array}$ & $\begin{array}{l}23 \\
22\end{array}$ & $\begin{array}{l}24 \\
22\end{array}$ & $\begin{array}{l}22 \\
20\end{array}$ & $\begin{array}{l}20 \\
20\end{array}$ & $\begin{array}{l}20 \\
20\end{array}$ & $\begin{array}{l}22 \\
20\end{array}$ & 21,5 \\
\hline
\end{tabular}


Em intervalos de sete diws foram retirados três frascos de cada tratamento, correspondendo às três repetições de cada semana, para se proceder as determinações analíticas.

Para facilidade de compreensão é apresentado abai xo um esquema da sequência de operações realizadas para obten ção dos dados de cada uma das parcelas.

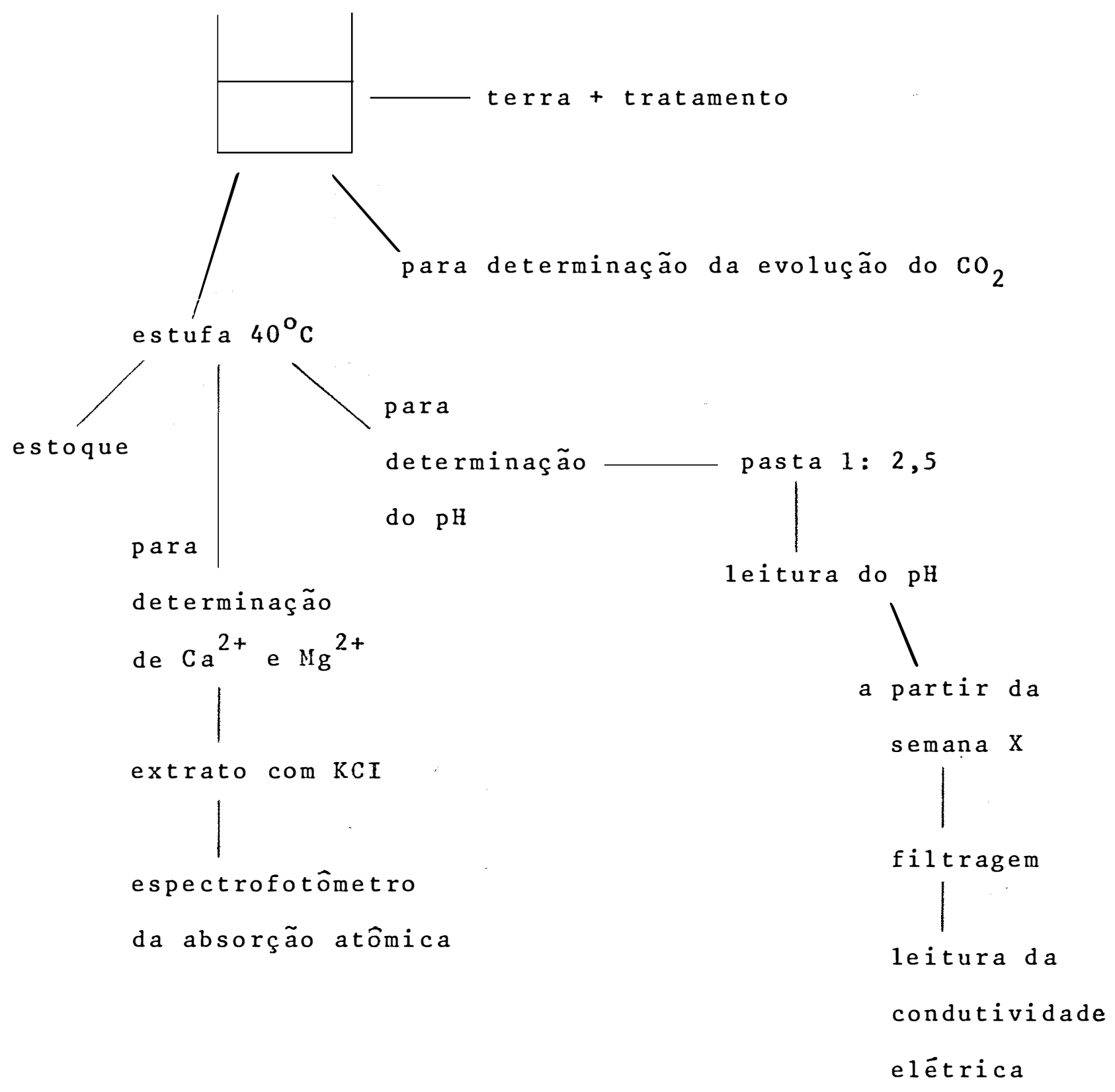




\subsubsection{Medida da Evolução do $\mathrm{CO}_{2}$ do solo}

A medida da quantidade de $\mathrm{CO}_{2}$ desprendida do solo foi feita pelo método de absorção por NaOH $1 \mathrm{~N}$ e posterior titulação com HCI IN descrito por PARKINSON et alii (1972). Es se método baseia-se na ocorrência da seguinte reação:

$$
\mathrm{CO}_{2}+2 \mathrm{NaOH} \longrightarrow \mathrm{Na}_{2} \mathrm{CO}_{3}+\mathrm{H}_{2} \mathrm{O}
$$

Amostras de solo retiradas dos frascos foram transferidas para cadinhos de porcelana que foram colocados em frascos de vidro com capacidade de um litro, juntamente com um recepiente devidro contendo $5 \mathrm{ml}$ de $\mathrm{NaOH}$ lN. Esses frascos foram fechados com tampa de plāstico. Para vedação satisfatória utilizou-se massa para calafetar em torno das tampas. Um frasco adicional, sem terra, foi preparado da mesma forma para determinar $\mathrm{O}_{2} \mathrm{CO}_{2}$ presente no meio.

\subsubsection{Determinação do pH}

0 pH do solo foi determinado na suspensão de uma mistura de solo: āgua na proporção de $1: 2,5$.

3.2.2.6. Determinação do teor de cálcio e magnẹ sio trocáveis

o extrato de solo para determinar os íons de $\mathrm{Ca}^{2+} \mathrm{e} \mathrm{Mg}^{2+}$ trocáveis foi obtido de $5 \mathrm{~g}$ de terra adicionados 
a $50 \mathrm{ml}$ de solução KCI $1 \mathrm{~N}$, agitados por 15 minutos e deixados em repouso por uma noite. A determinação dos íons $\mathrm{Ca}^{2+}$ e $\mathrm{Mg}^{2+}$ no extrato foi feita por espectrofotometria de absorção atômica.

\section{2 .2 .7 . Condutividade elétrica}

A condutividade elétrica foi determinada em extrato filtrado de uma mistrua solo: água na proporção 1:25. As medidas foram feitas com condutivimetro. 


\section{RESULTADOS}

A evolução do $\mathrm{CO}_{2}$, o $\mathrm{pH}$ e a perda de água por evaporação foram medidos todas as semanas, e os teores de cấ1cio e de magnésio trocáveis foram medidos quinzenalmente. Determinou-se também a condutividade elétrica de cada tratamento nas três $\bar{u} l t i m a s$ semanas.

A média das três repetições de cada tratamento em cada período de tempo, serão apresentadas em quadros que mostram, também, os parâmetros estatísticos da. anālise de variância e os valores da diferença mínima significativa (DMS) utilizados para comparar as médias, de acordo com o teste de Tukey. Os resultados aparecerão, tambēm, na forma de gräficos para facilitar a observação das variações que ocorreram durante a incubação. Os tratamentos serão identificados pela primeira letra do nome do material $(S=$ Soja, $C=$ Composto, $M=$ Pa1ha de Milho, $B=$ Bagaço de Cana) precedida pelo nümero que indica a dosagem aplicada ( $5 \%$ ou $10 \%)$. 
Serão incluídos, no ítem 4.6., dados de pH obtidos em uma incubação de quatro semanas, realizada após o tërmino do experimento, para verificar algum possível efeito no pH da colocação do papel alumínio sobre os frascos.

Inicialmente serão apresentados os resultados relativos a evolução do $\mathrm{CO}_{2}$, ao $\mathrm{pH}$ e ao cälcio e ao magnésio trocáveis por serem os dados que mais se relacionam com a decomposição da matéria orgânica e a solubilização do calcärio.

$$
\text { 4.1. EVOLUÇÃO DO } \mathrm{CO}_{2}
$$

Os valores da quantidade de $\mathrm{CO}_{2} \mathrm{liberado}$, pelos tratamentos são mostrados de duas maneiras: os valores obtidos a cada intervalo de sete dias, no QUADRO 6, e os valores acumulados, no QUADRO 7. Para esses dados não foi feita a añ lise de variância porque só houve uma determinação a cada semana para os tratamentos estudados.

Na primeira semana, a respiração do solo foi alta, para em seguida sofrer uma queda acentuada em todos os tratamentos. 


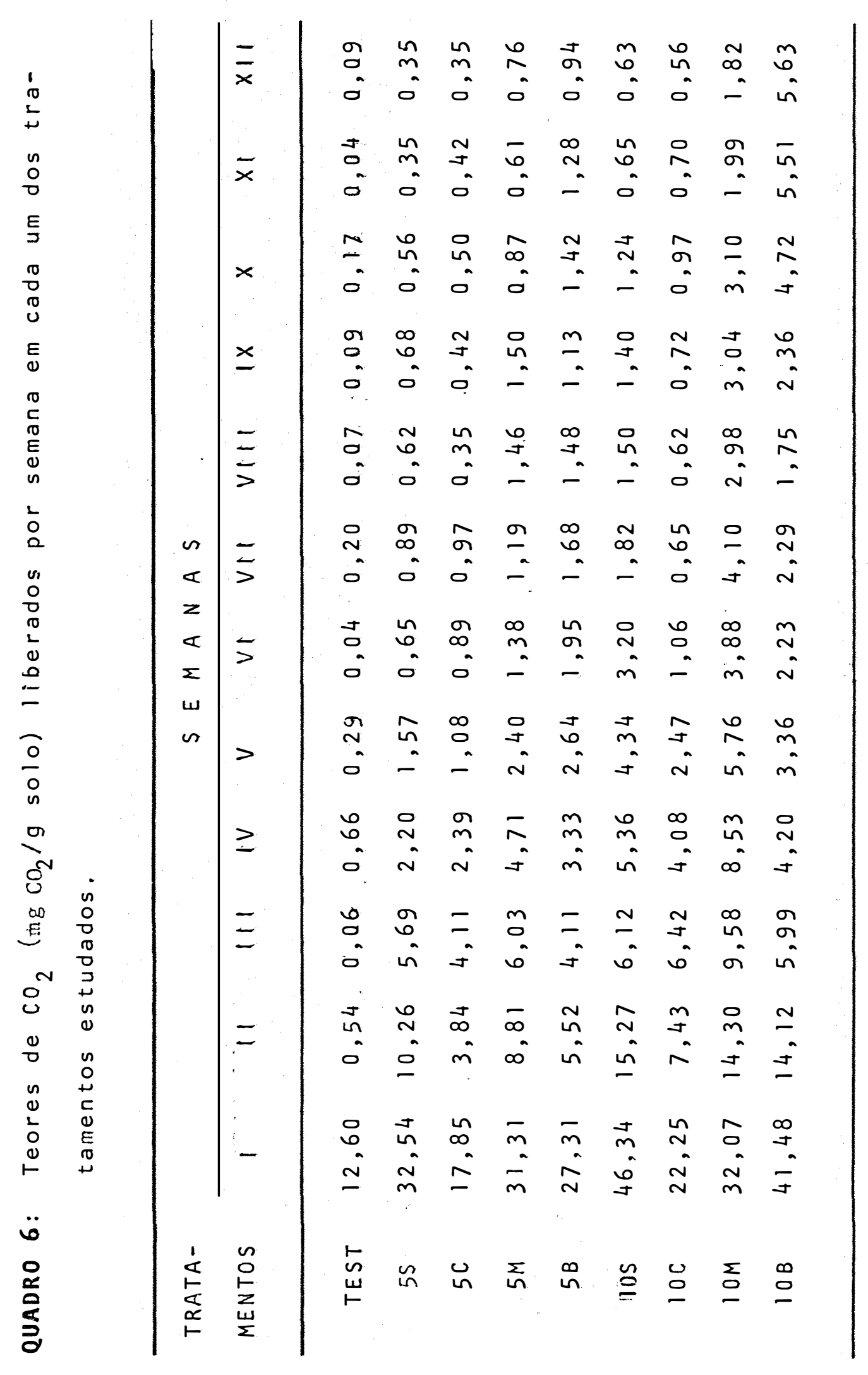

42 


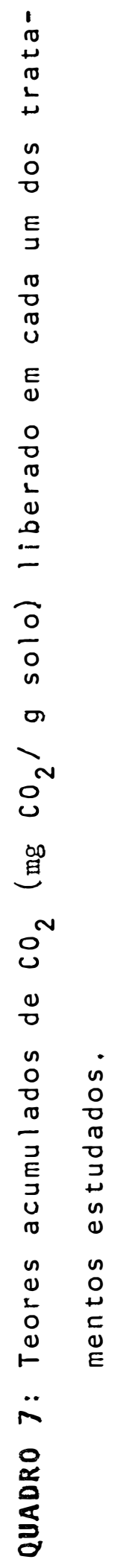

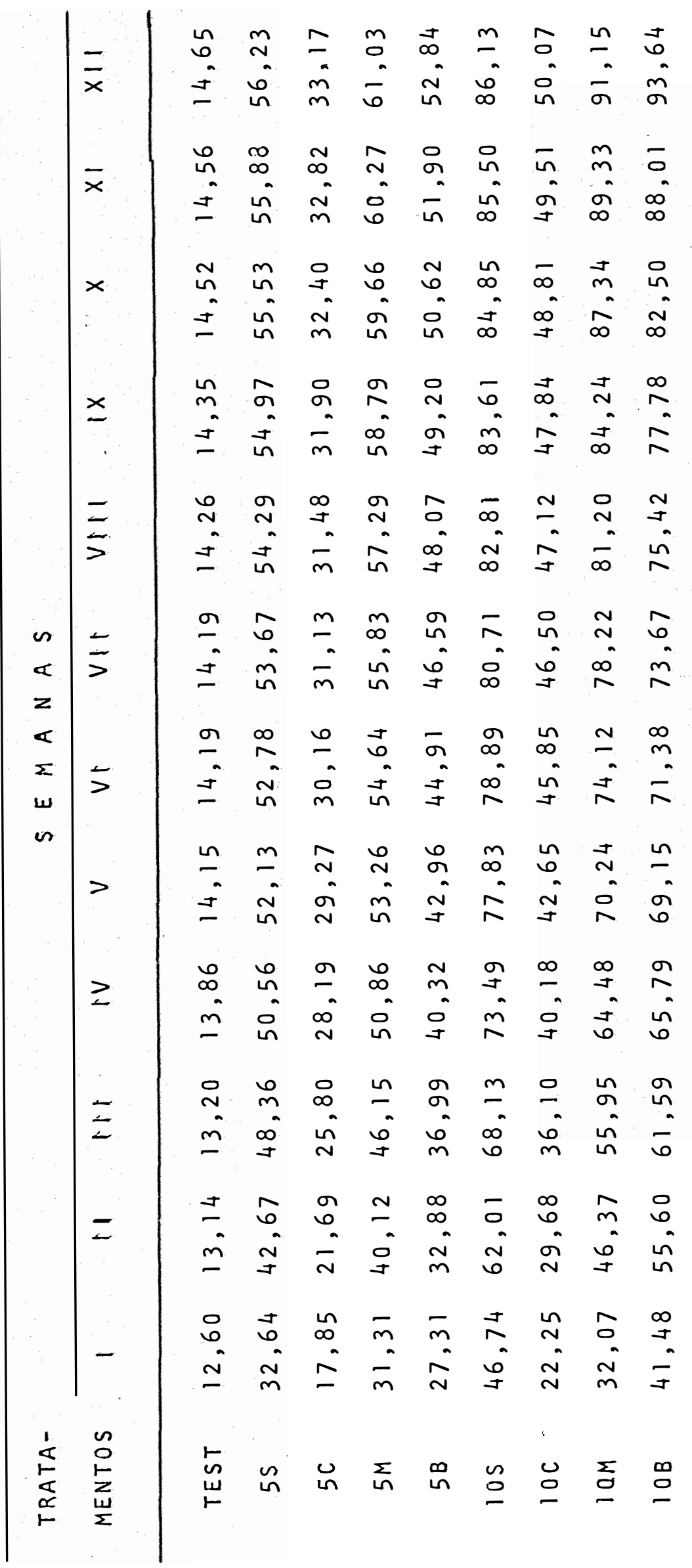


Nas parcelas que receberam a dose de $5 \%$ de matéria orgânica ocorreu uma progressiva e lenta diminuição na diferença entre os tratamentos, como podemos ver na FIGURA 1 . Nas parcelas com a dose de $10 \%$ de matéria orgânica, a evolução do $\mathrm{CO}_{2}$ apresentou diferenças relativamente maiores entre os tratamentos do que no caso da dose de $5 \%$, conforme observa-se na FIGURA 2. Durante o decorrer da incubação, os tratamentos com a maior dose de matéria orgânica apresentaram; respectivamente, maior taxa de respiração do que os com $5 \%$ de matéria orgânica, em todo o período de incubação.

A partir da quantidade total de $\mathrm{CO}_{2}$ evoluído (QUADRO 7), e da quantidade de carbono no início da incubação, em cada tratamento, estimou-se o teor de carbono remanescente e a porcentagem de perda de carbono. Esses resultados estão no QUADRO 8. Nota-se que a porcentagem de carbono perdido pela respiração é mais baixa no tratamento testemunha do que nos outros tratamentos. E nesses é mais baixa para a dose de $5 \%$ do que para a dose $10 \%$ de matéria orgânica. Apenas no caso do tratamento composto houve semelhança na porcentagem de carbono perdido em ambas as doses. 


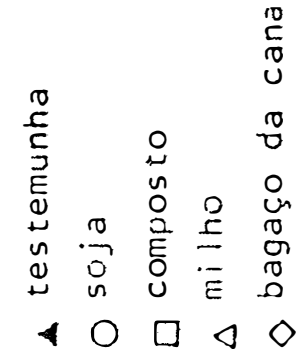

$$
\begin{aligned}
& 40 \text { प } 40
\end{aligned}
$$
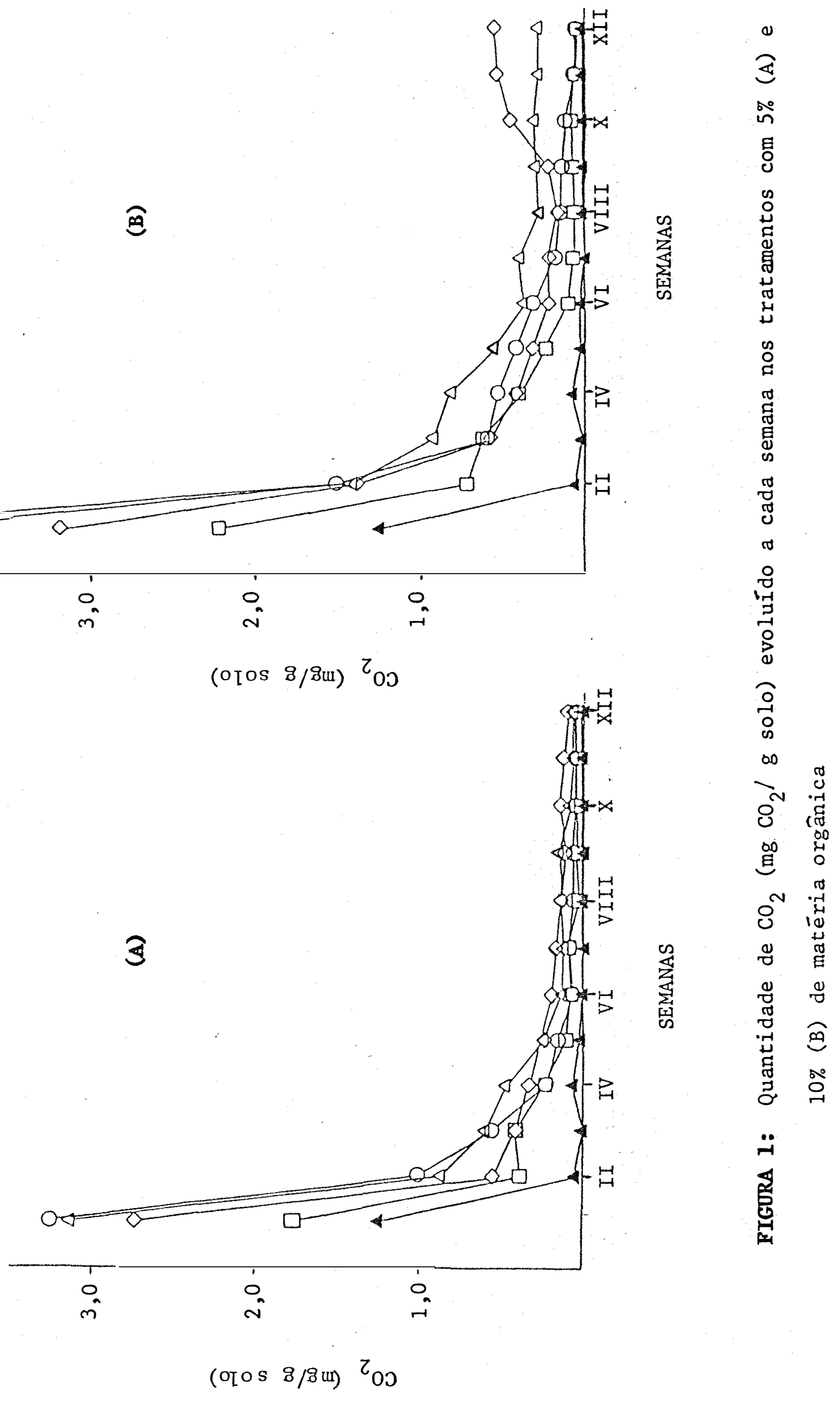
QUADRO 8: Teores de carbono (mg C/g solol inicial, evoluido e final, e a porcentagem de carbono perdido na forma de $\mathrm{CO}_{2}$ em relação ao teor inicial, para os trata mentos estudados

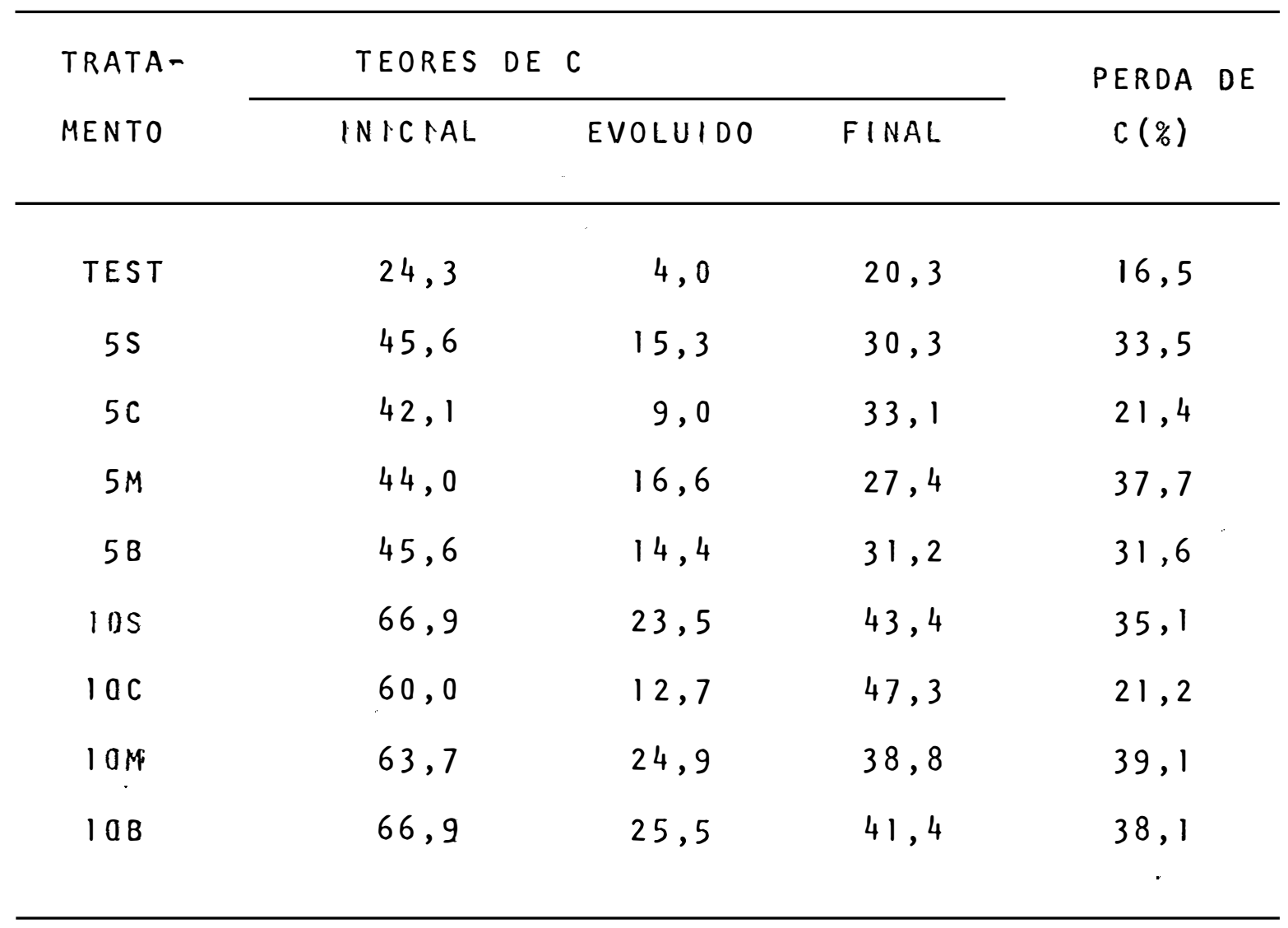




\section{2. $\mathrm{pH}$ DO SOLO}

0 pH do solo foi medido semanalmente e os resultados obtidos encontram-se no QUADRO 9. Nesse quadro estão também os valores de pH no início da incubação (To = tempozero) medidos um dia após a montagem do experimento,sem repetif̧ão. Nota-se que a presença da matéria orgânica em decomposição alterou o pH do solo, pois a anälise estatística indicou que houve diferença significativa entre os tratamentos.

Em relação ao tratamento testemunha, sem matéria orgânica, os outros tratamentos apresentarem um pH mais elevado. As FIGURAS $2 \mathrm{~A}$ e $2 \mathrm{~B}$ ilustram esse fato. Observa-se, também, uma elevação acentuada do pH, nas duas primeiras semanas, nos tratamentos que receberam soja ( $5 \mathrm{~S}$ e 10S). Durante a incubação o pH, nos diferentes tratamentos, sofreu alterações, mas houve uma tendência à estabilização nas ūltimas semanas.

Ao final das doze semanas de incubação, comparando-se os tratamentos com a dose de $5 \%$, verifica-se que o bagaço de cana apresentou o maior valor de pH, seguido dos materiais milho, soja e composto. Nos tratamentos com dose $10 \%$ porem, houve um comportamento diferente, com o bagaço de cana apresentando valores de pH mais baixos que os outros materiais. 


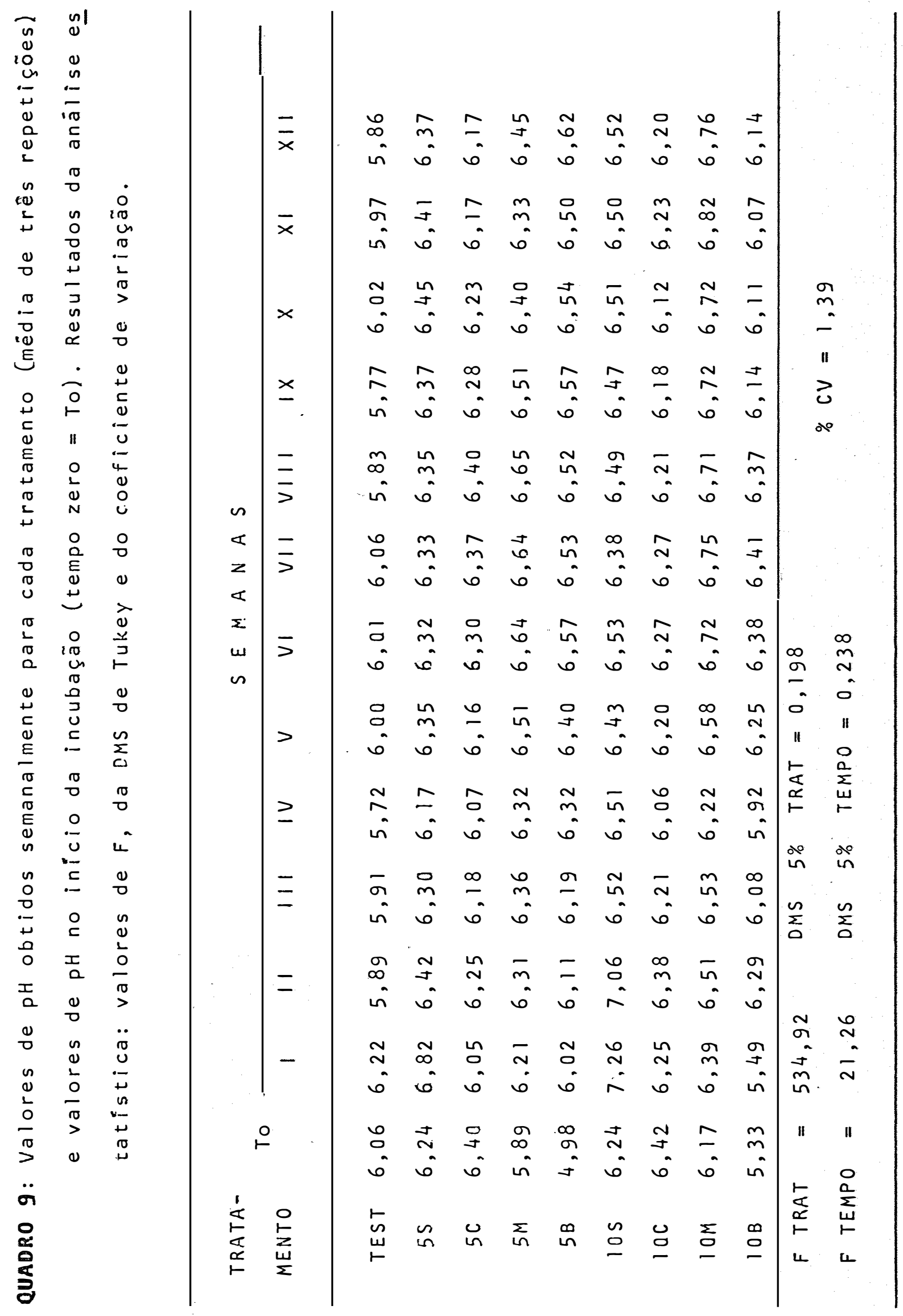




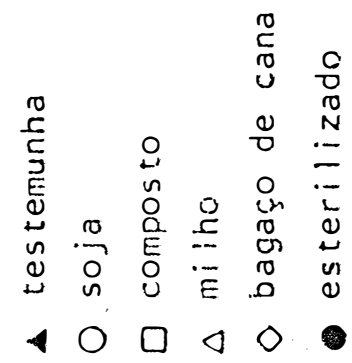

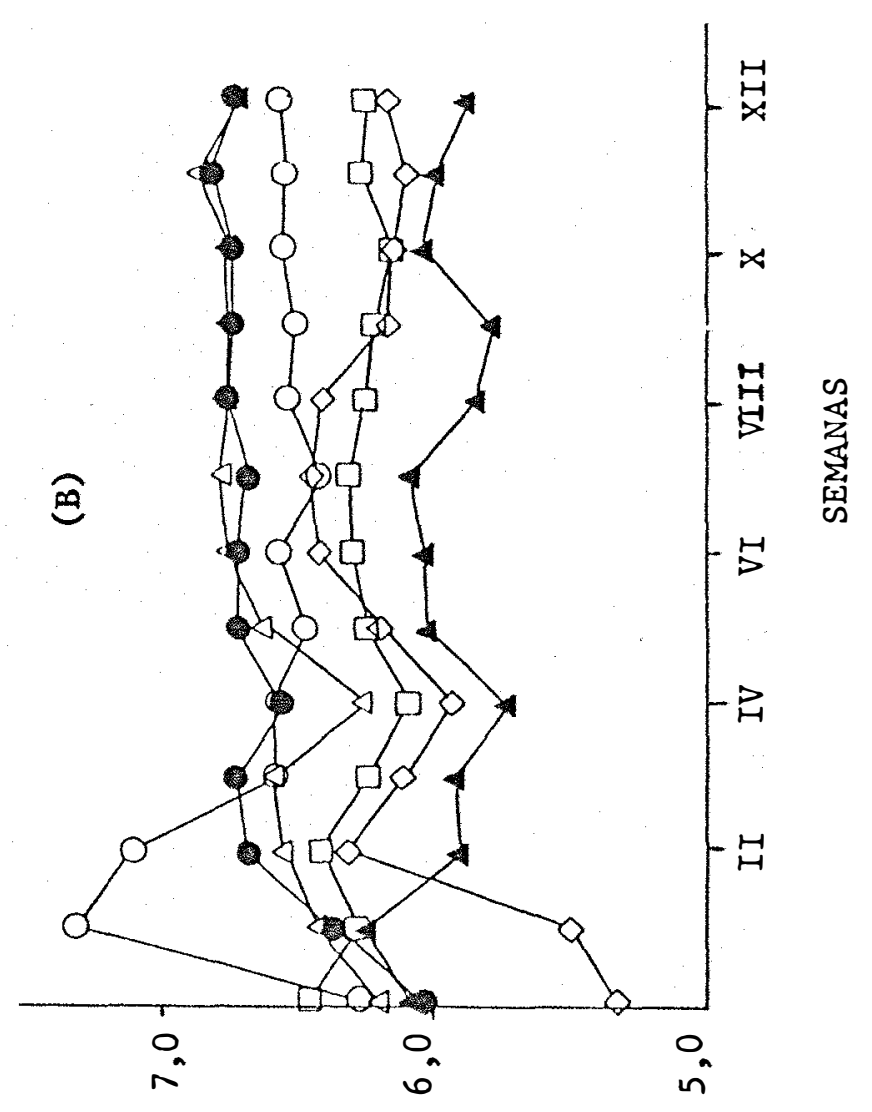

49.

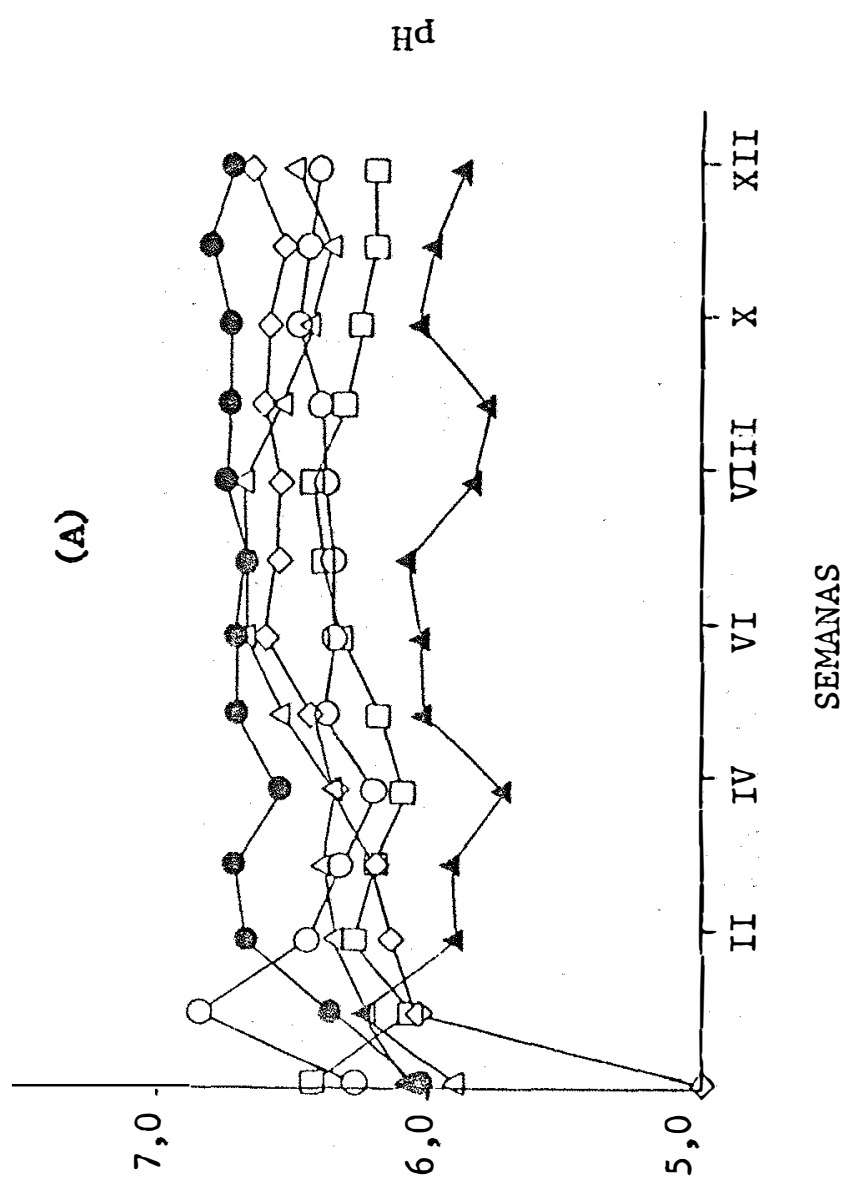

$\mathrm{Hd}^{\mathrm{d}}$ 


\subsection{CALLIO E MAGNESIO TROCÄVEIS}

os teores de cālcio e de magnésio trocáveis obtidos estão em dois quadros: o QUADRO 10 para os valores de $\mathrm{Ca}^{2+}$ trocável e o QUADRO 11 para os valores de $\mathrm{Mg}^{2+}$ trocável.

$$
\text { os resultados mostram que os teores de cálcio e }
$$
de magnésio aụmentaram, principalmente durante os primeiros quinze dias. A anälise estatística mostrou, porém, que o teor de magnésio continuou tendo aumentos significativos at $\ddot{~ a ~ q u a r t a ~}$ semana .

De maneira geral, os tratamentos com a dose $10 \%$ de matéria orgânica apresentaram valores mais elevados de $\mathrm{Ca}^{2+}$ e de $\mathrm{Mg}^{2+}$ do que os que receberam a dose $5 \%$. Para o cälcio,porēm, essas diferenças nem sempre foram significativas.

os maiores valores, tanto de cálcio quanto de magnésio, foram apresentados pelos tratamentos que receberam composto. Os tratamentos com soja e milho tiveram valores mais baixos desses íons que os tratamentos com composto, mas na $\bar{u} 1-$ tima semana esses três tratamentos não foram significativamente diferentes. (Ver FIGURAS 3, e 4).

o tratamento bagaço de cana, nas duas doses empregadas, apresentou os menores valores de cälcio e de magnésio trocáveis, mais baixos atē mesmo que os do tratamento testemunha . 
51.

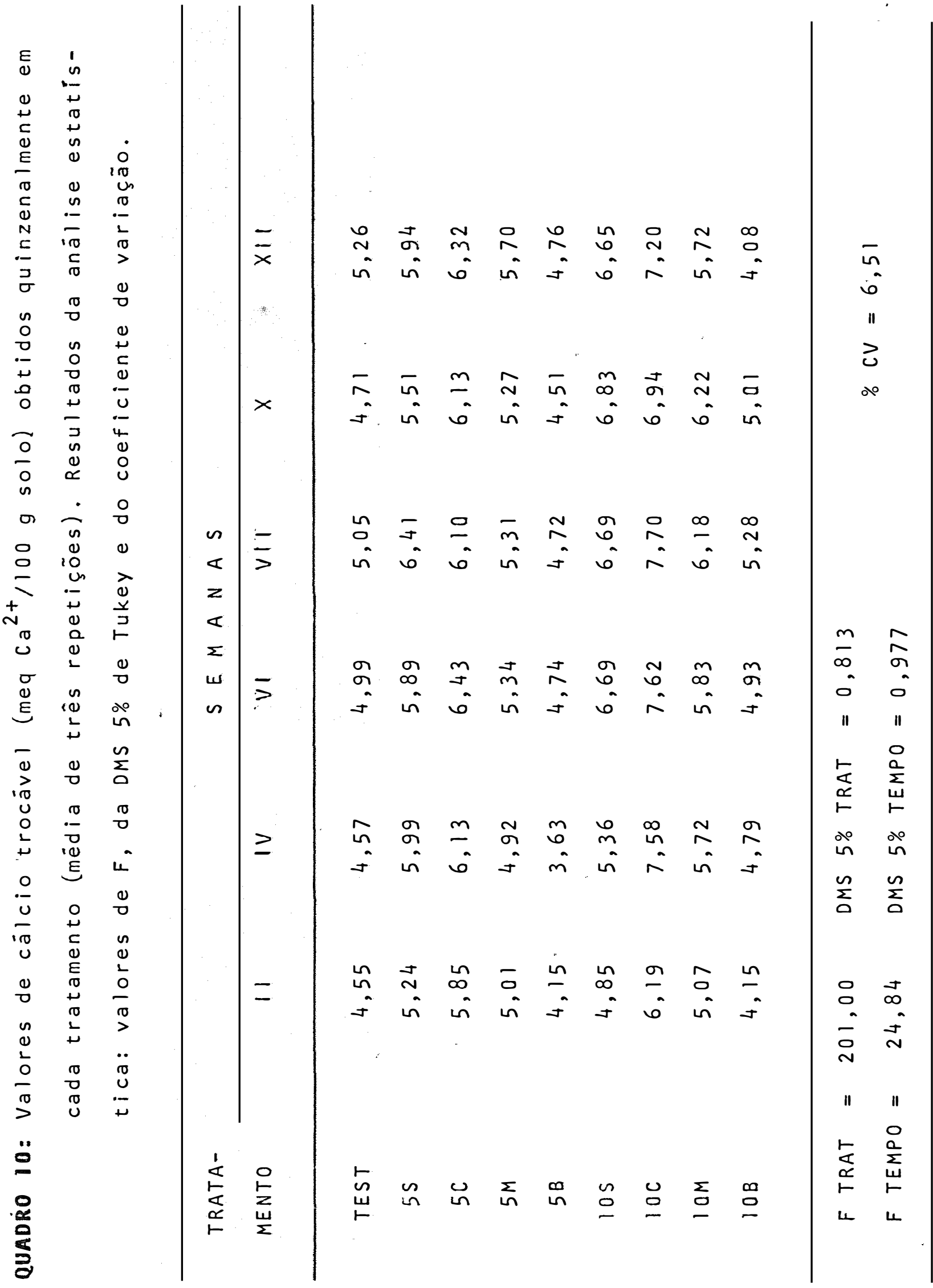




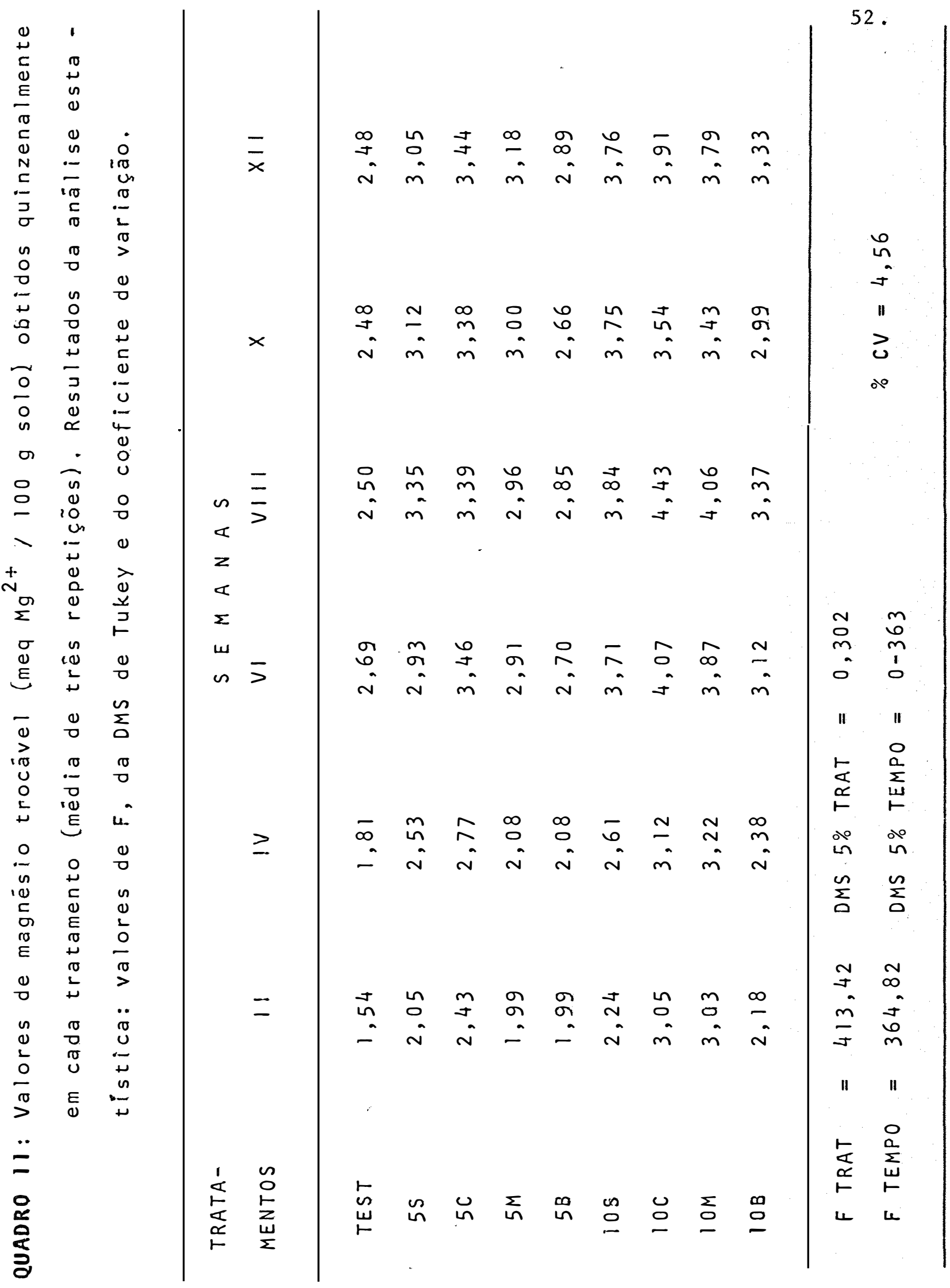




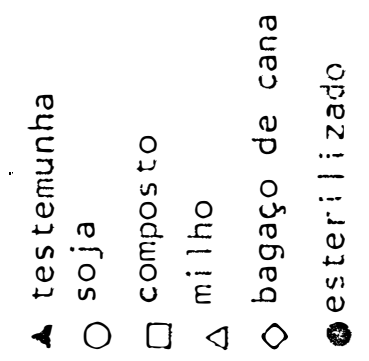

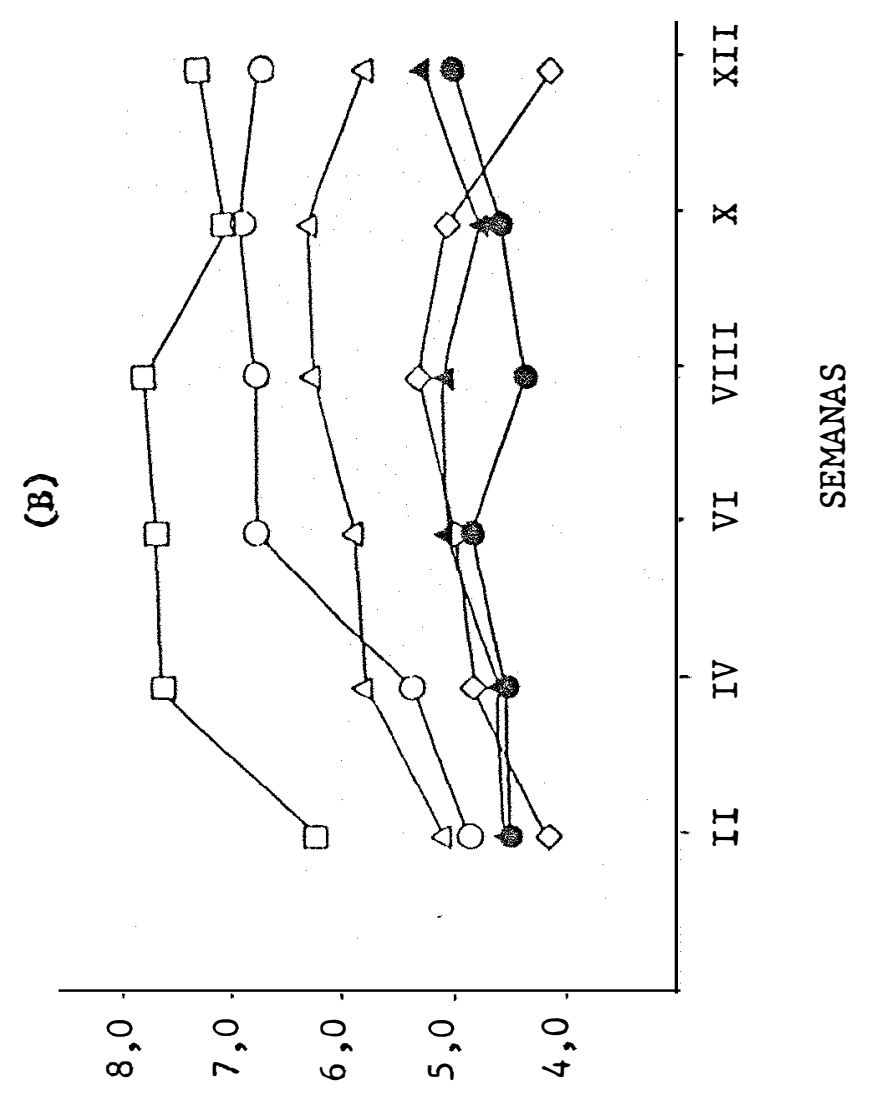

ह 53.
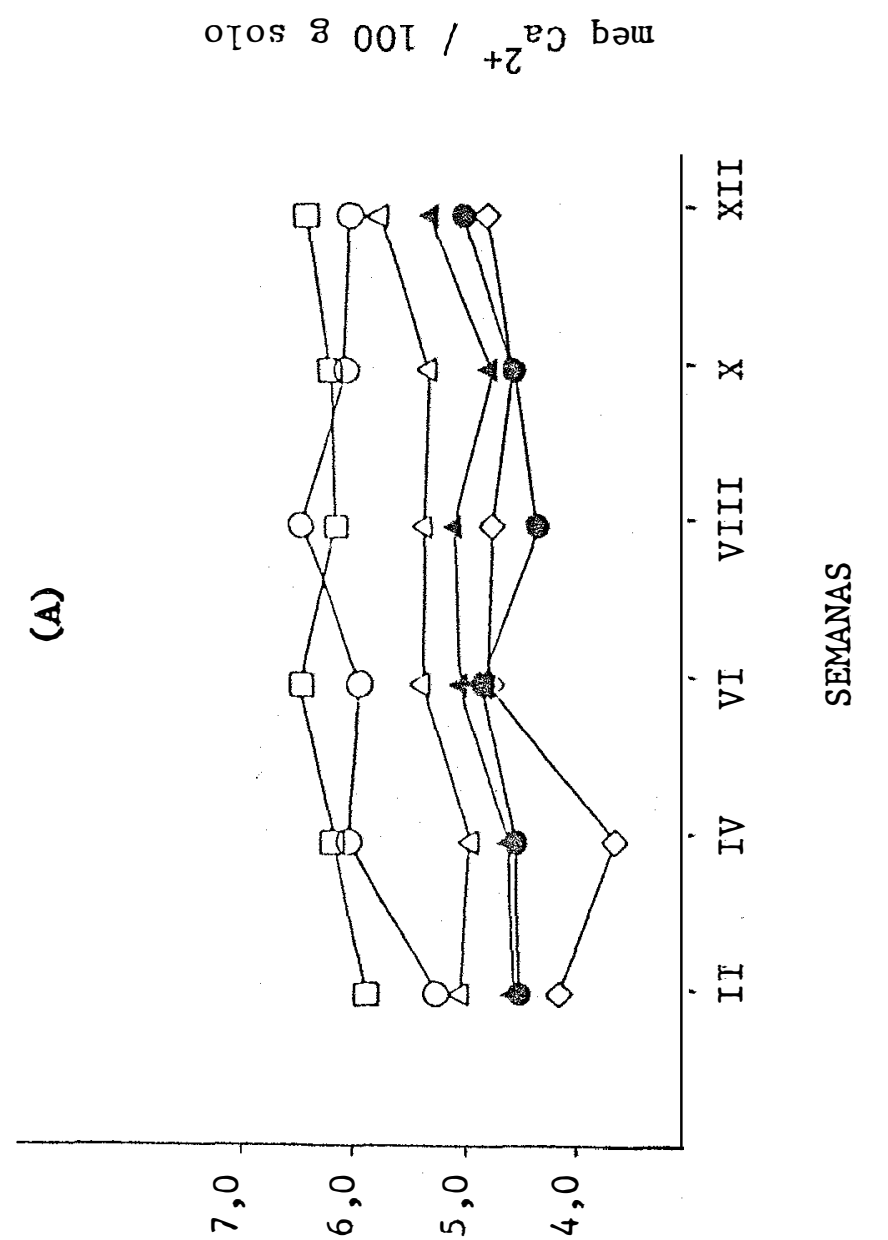

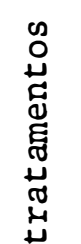

c

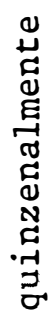

告

官

$\infty$

욱

7

$\stackrel{+}{\sim}$

$\dot{8}$

(⿻)

$\begin{array}{ll}0 & \infty \\ \Xi & 0 \\ \Xi & 0\end{array}$

离

ํㅜㄹ

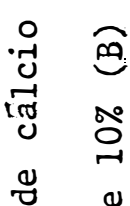

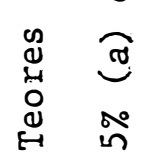

in

olos 8 00t $/{ }^{6+}$ ej baur 

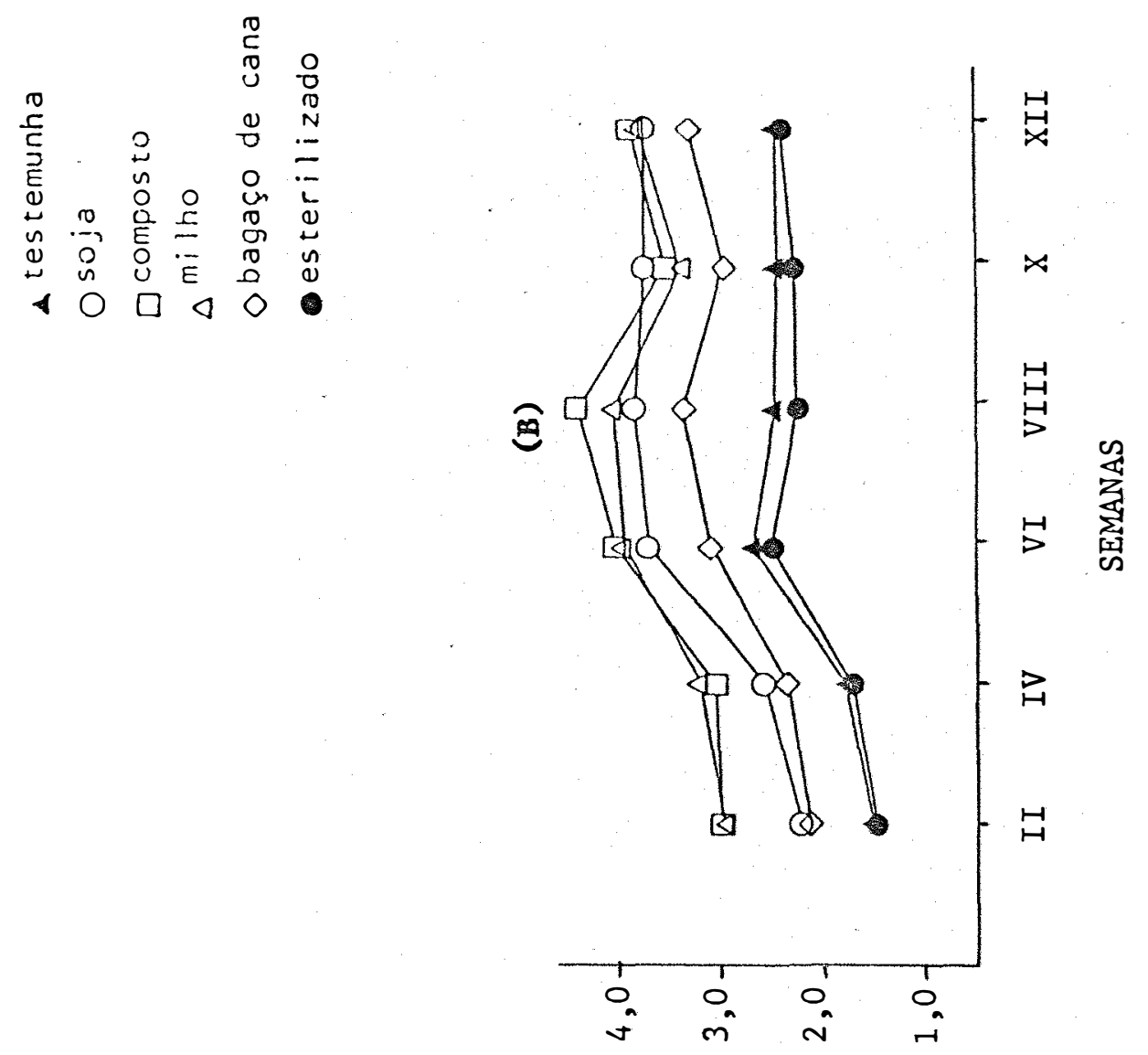

ํํำ

54.

olos .8 00L $1+z^{8} \mathrm{~W}$ bəu

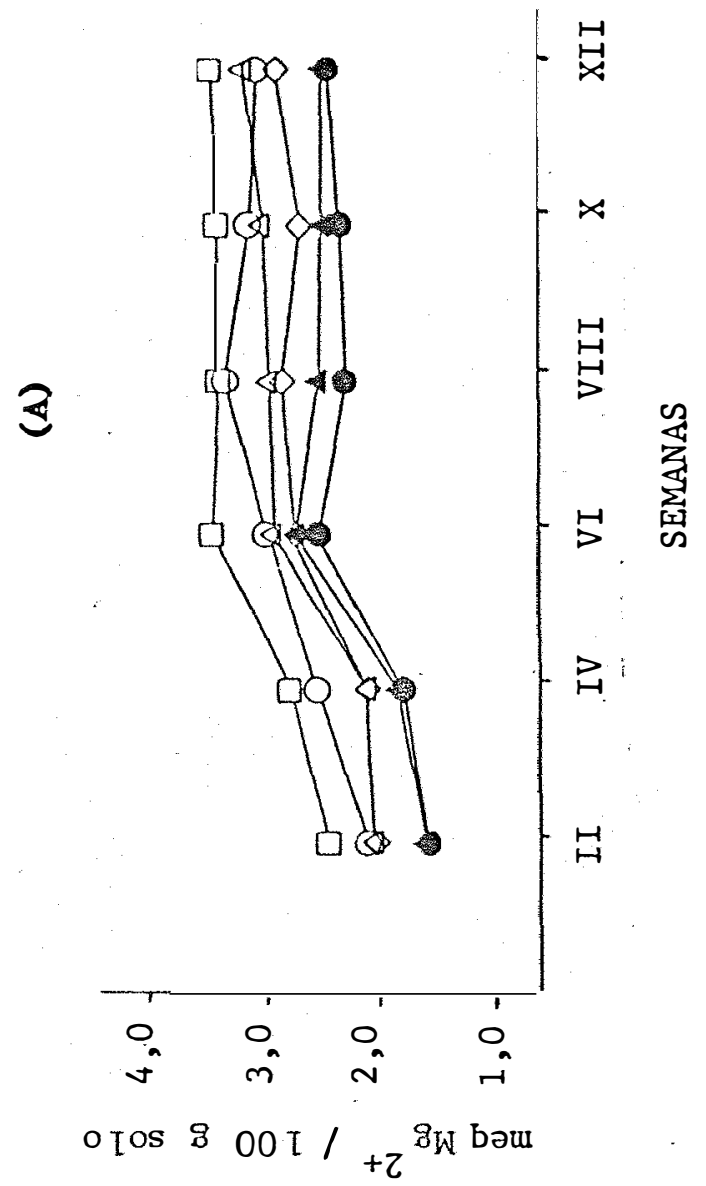

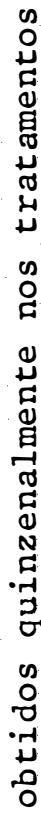

ô
o
is

$\infty$

음

$>$

$\stackrel{+}{\mathrm{N}_{0}}$ ช்

$\Sigma$

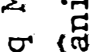

过

$\vec{d} \cdot \pi$

id

品

$\circ$ ชั

iू

竞

苗

ขै

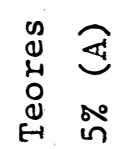

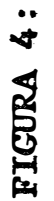




\subsection{TRATAMENTO ESTERILTZADO}

o tratamento esterilizado seguiu os mesmos passos dos outros tratamentos quanto a obtenção dos resultados. A evolução do $\mathrm{CO}_{2}$ foi determinada, mas os valores foram muitos elevados. Na primeira semana a respiração atingiu $26,69 \mathrm{mg}$ de $\mathrm{CO}_{2} / \mathrm{g}$ de solo, valor mais alto que o apresentado pelos tratamentos testemunha $\left(12,60 \mathrm{mg} \mathrm{Co}_{2} / \mathrm{g}\right.$ solo $)$ e o composto $(17,85$ e $22,25 \mathrm{mg} \mathrm{CO}_{2} / \mathrm{g}$ solo, respectivamente para $5 \%$ e $10 \%$ de matéria orgânica). o frasco utilizado para determinação da evolução do $\mathrm{CO}_{2}$ do tratamento esterelizado também foi esterelizado com clorofórmio. Mas ocorreram problemas com a vedação do frasco,permitindo a entrada de $\mathrm{CO}_{2}$. Como esse fato continuou ocorrendo nas semanas seguintes, esses resultados não foram considerados.

Entretanto, dentro dos dessecadores, onde estavam incubados os frascos do tratamento esterilizado, o ambiente provavelmente continuava em condições estéreis, e, por isso, prosseguiu-se com as determinações de pH e de cálcio e de magnésio trocāveis.

os resultados desse tratamento, que estão nos QUADROS 12 e 13, serão comparados apenas com o tratamento testemunha, jā que nenhum dos dois recebeu adição de matéria orgânica. As FIgURAS 3 e 4 apresentadas anteriormente, contém, támbem, os resultados do tratamento esterilizado, permitindo uma comparação com os outros tratamentos. 
56.

Pode-se notar, pelos resultados encontrados, que

o tratamento esterilizado alcançou valores mais elevados de pH e teores mais baixos de cálcio e magnésio trocáveis que o tratamento testemunha. 


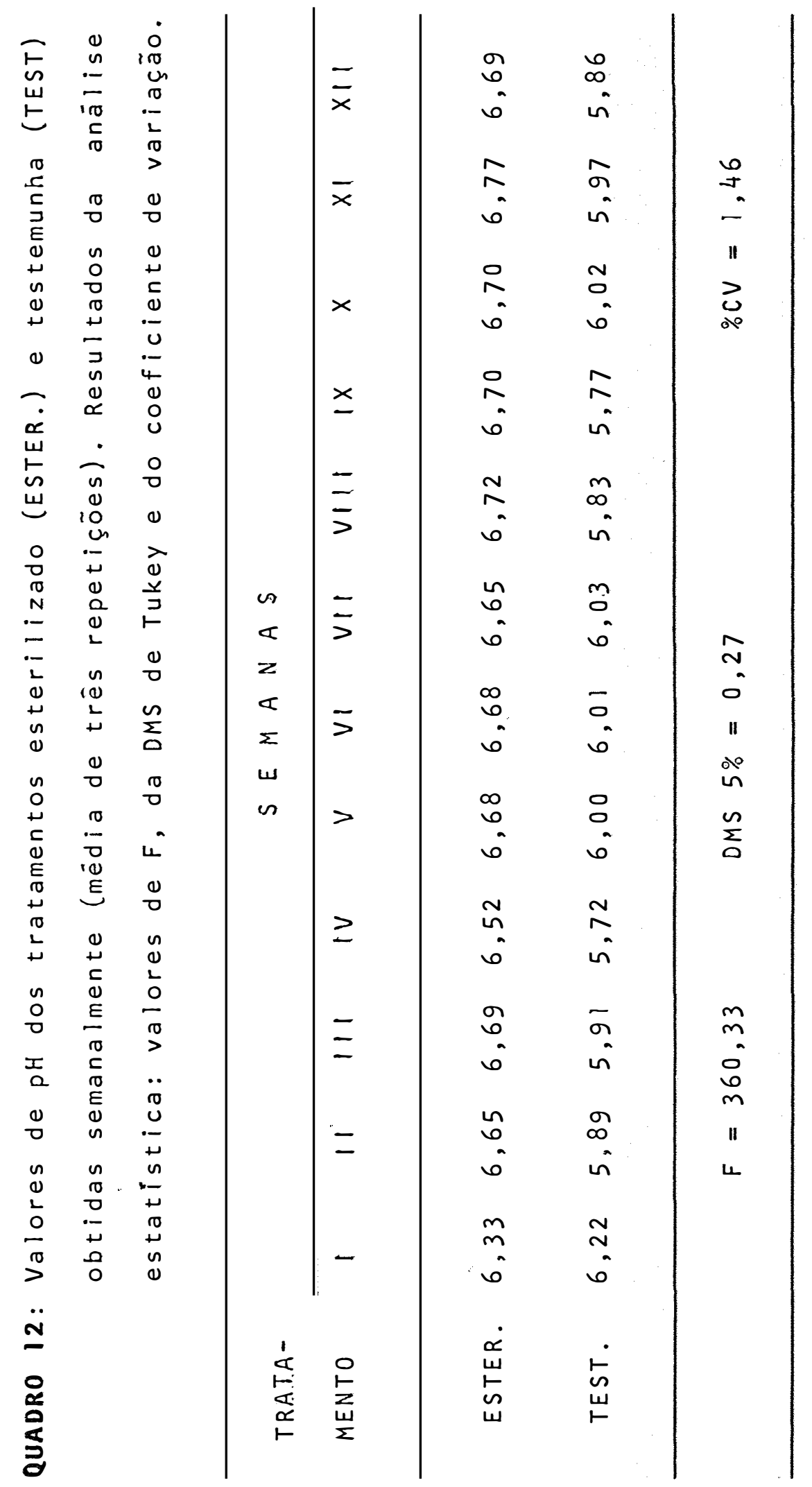



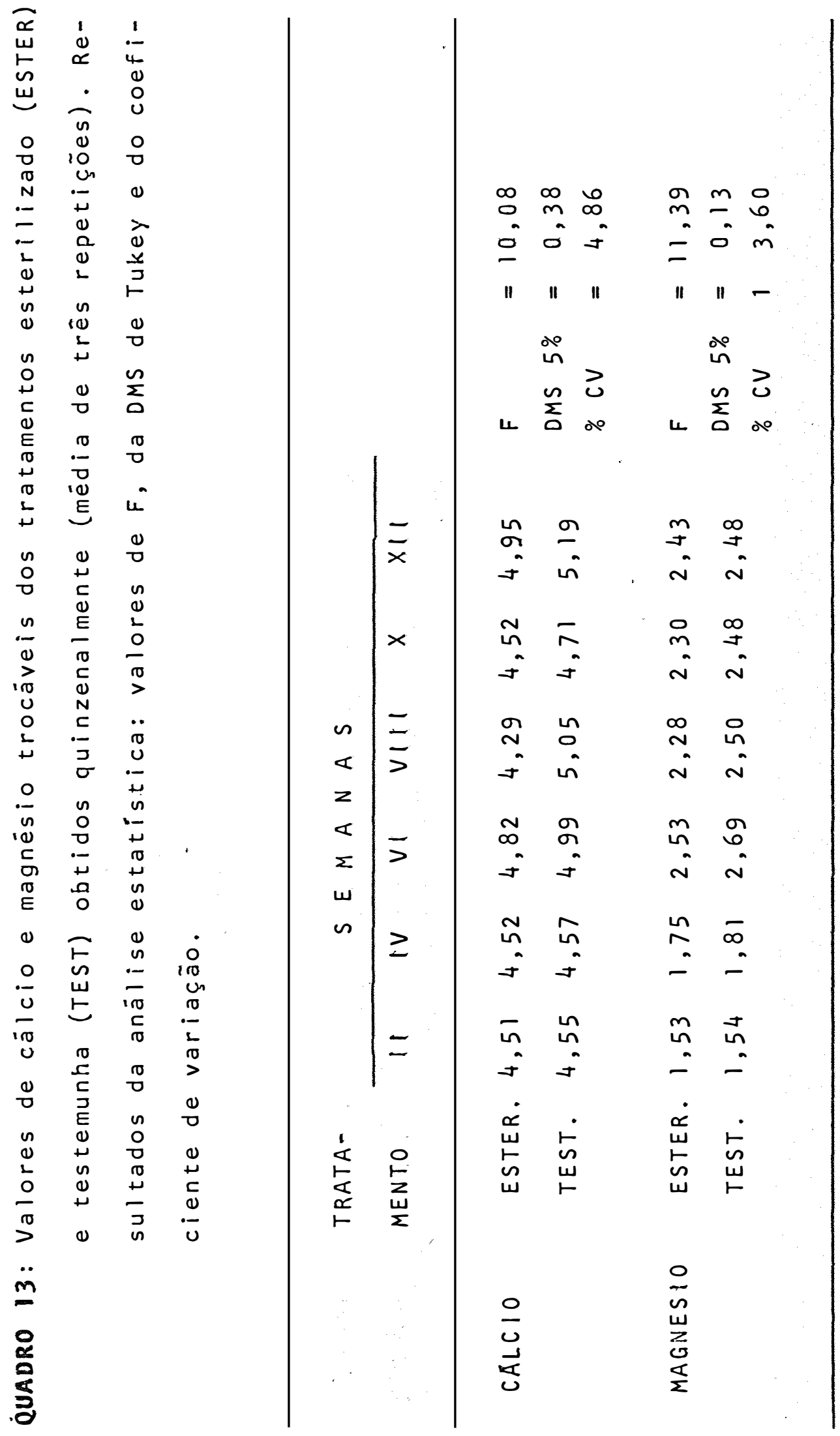
4.5. PERDA DE $\overparen{A G U A}$

A perda de água por evaporação foi avaliada pe1 a quantidade de água colocada nos frascos, a cada semana, para manter o grau de umidade pré-estabelecido.

Para analisar a perda de água, foram utilizados apenas os valores obtidos nos três ültimos frascos de cadatratamento, istóé, os frascos que permaneceramaté o final da incubação. Esses valores são apresentados no QUADRO 14.

A diferença significativa entre os tratamentos, indicada pelo teste de F, é devido a diferenças ocorridas nas primeiras semanas. A ordenação dos tratamentos em relação a quantidade de água perdida, porém, variou a cada semana. Em relação à dose empregada não houve diferença significativa.

A anālise estatística mostrou, ainda, que a perda de ägua diminuiu com o tempo de incubação. Isto deve estar relacionado com a diminuição da temperatura média no laboratório (ver QUADRO 5). Ou, possivelmente, com a diminuição na taxa de decomposição.

Esses resultados não concordam com os obtidos por costa (1983), que verificou maior evaporação com o aumento da quantidade de matéria orgânica adicionada. Assim, o papel de alumínio fechando os frascos exerceu um controle sobre a perda de água. As variações observadas são atribuidas a acidentes no laboratörio. 
60.

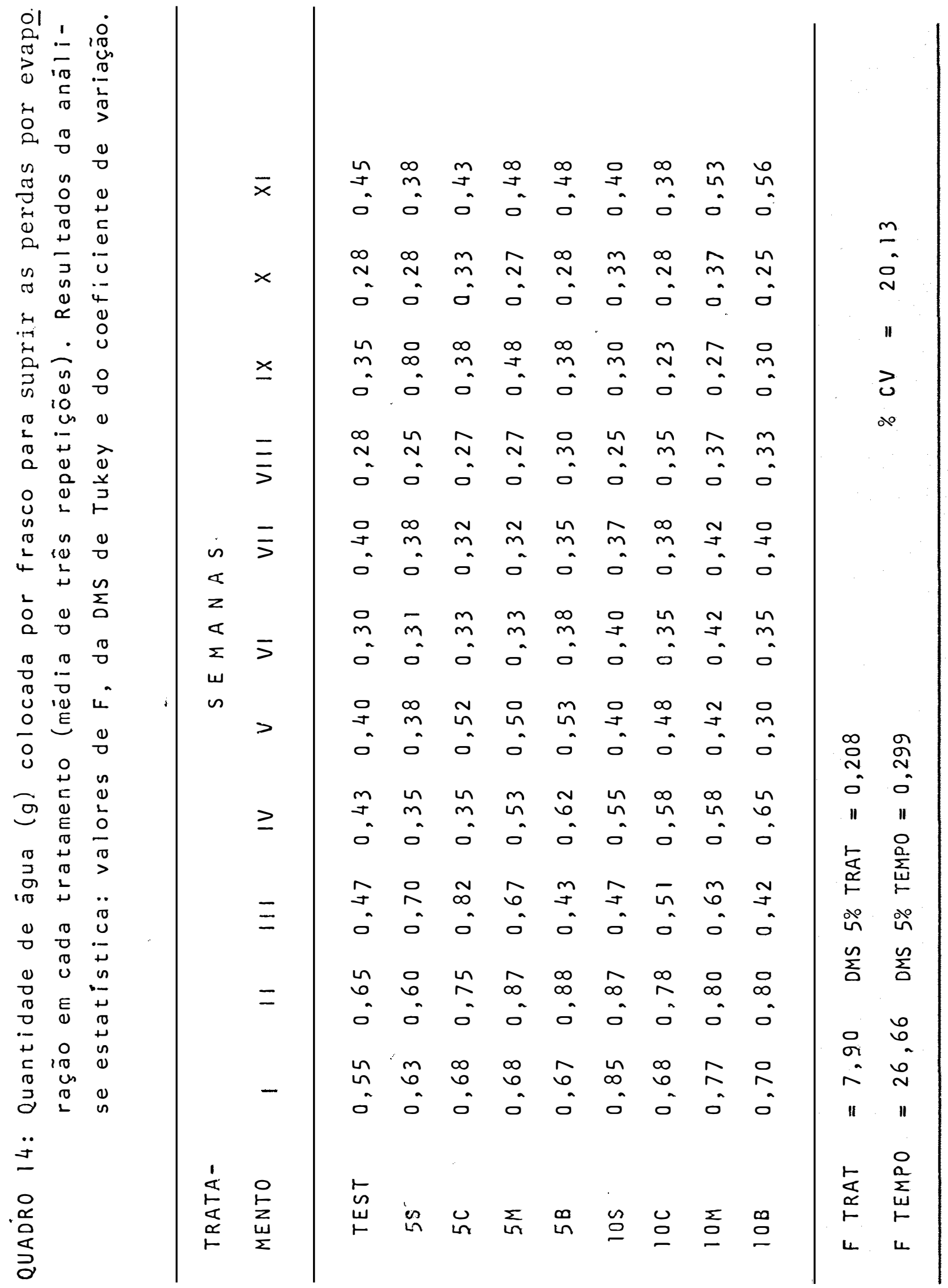




\subsection{CONDUTIVIDADE ELETRICA}

A condutividade elétrica foi medida para verificar se as variações do pH ocorridas nos tratamentos estudados poderiam ser devidas a uma variação no teor de sais presentes na solução do solo. As determinações foram feitas nas três ültimas semanas (X, XI e XII). Os dados obtidos encontramse no QUADRO 15.

A anảlise estatística mostrou diferenças entre os tratamentos. De fato, nota-se, claramente, uma diferença entre os tratamentos soja e composto e os tratamentos milho, bagaço de cana e testemunha. Os dois primeiros apresentaram condutividade elétrica mais elevada.

os valores da condutividade elétrica dos tratamentos não apresentaram correlação com os valores de pH $\left(r^{2}=0,052\right)$, mas apresentaram correlação com os valores de $\mathrm{Ca}^{2+}+\mathrm{Mg}^{2+}$ trocäveis $\left(\mathrm{r}^{2}=0,785\right)$. 
QUADRO 15: Condutividade elëtrica (m mhos/cm) determinada nas três últimas semanas ( $x, x l$ e $x I l)$ para cada trata mento (média de três repetições). Resultados $\because$ da anälise estatística: valores de F, da DMS de Tukey e coeficiente de varíação

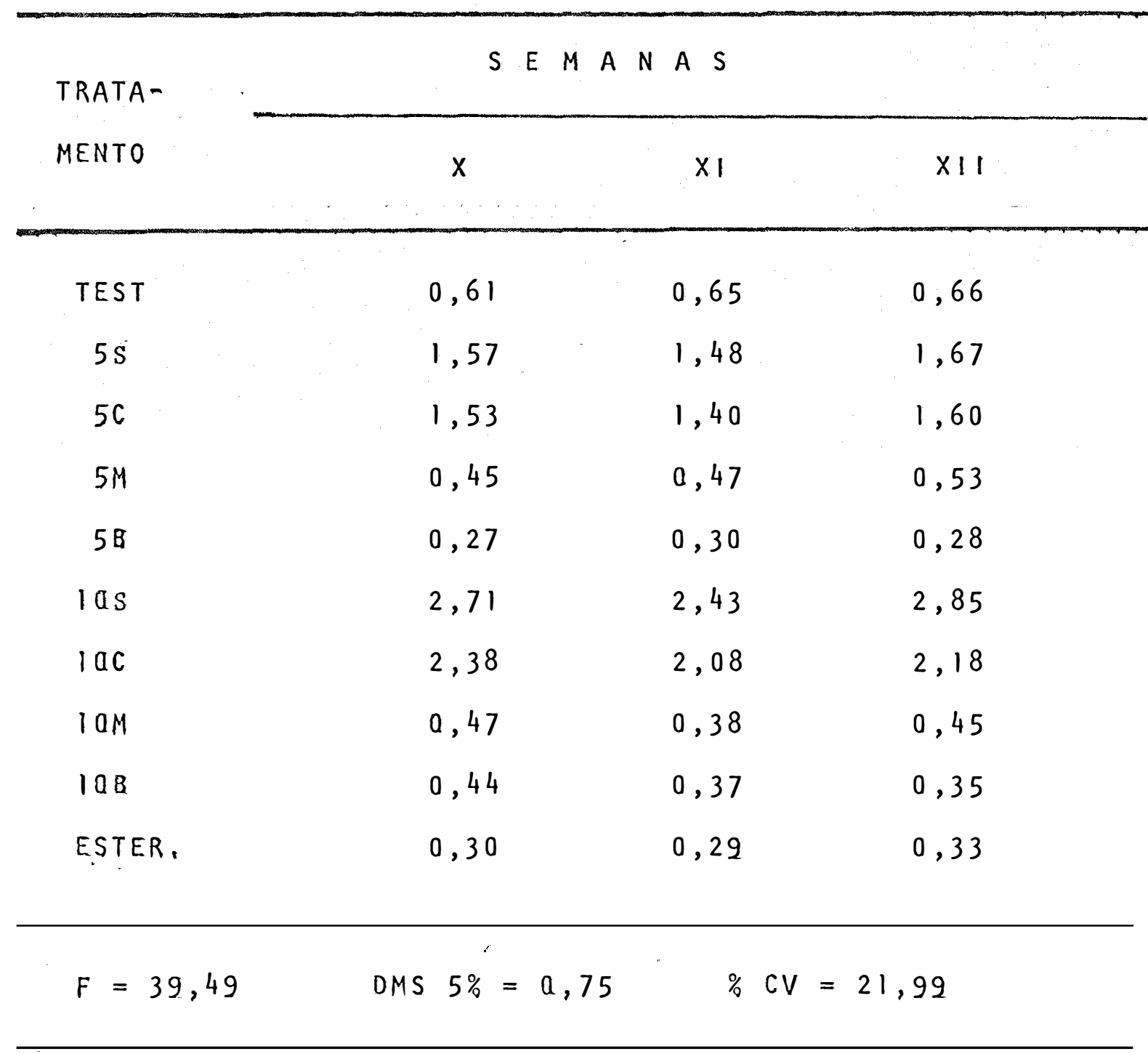




\subsection{EFEITO DA RESTRIÇ̃̃O IMPOSTA Ā LIVRE DIFUS ÃO}

Para verificar se a presença do papel de alumínio cobrindo os frascos poderia influenciar na difusão do $\mathrm{Co}_{2}$ e alterar os valores de pH do meio pelo acúmulo de ácido carbônico, foi montado um experimento paralelo, segundo um deliniamento fatorial $2^{2}$, em que os fatores eram: difusão ( 1 ivre e restrita) e presença de calcārio (sim e não). A restrição imposta à difusão foi a mesma que para o experimento principal, isto é, uma folha de papel de alumínio fechando a boca dos frascos

Nos mesmos frascos de vidro utilizados anteriormente incubou-se $40 \mathrm{~g}$ de solo sem adição de matéria orgânica durante 4 semanas, com 5 repetições. Os tratamentos foram:

- calcārio e difusão livre (C DL)

- calcārio e difusão restrita (C DR)

- sem calcārio e difusão livre ( $S$ DL)

- sem calcário e difusão restrita (S DR)

A cada semana, uma amostra de solo era seca em estufa a $40^{\circ} \mathrm{C}$ e usada para determinação do pH. Os resultados encontram-se no QUADRO 16. A diferença entre os tratamentos foi significativa, como indica o teste F. A restrição à difusão, na presença ou ausência de calcārio, provocou uma diminuição no pH. Essa diferença acentuou-se com o tempo, como podese observar, claramente, na FIGURA 5 . 
QUADRO 16: Valores de pH (média de 5 repetições) nos tratamentos do experimento fatorial $2^{2}$ Calcārio $x$ difusão do ar. Valores de F, da DMS de Tukey e do coeficiente de variação.

\begin{tabular}{lcccc}
\hline \multirow{2}{*}{$\begin{array}{l}\text { TRATA- } \\
\text { MENTO }\end{array}$} & I & II & III & IV \\
\cline { 2 - 5 } & 5,15 & 5,10 & 4,96 & 4,91 \\
CDR & 5,19 & 5,28 & 5,23 & 5,34 \\
CDL & 4,62 & 4,57 & 4,28 & 4,16 \\
SDR & 4,66 & 4,77 & 4,68 & 4,63 \\
SDL & & DMS & $5 \%=0,12$ & CV $\%=1,49$ \\
\hline F $=542,39$ & &
\end{tabular}

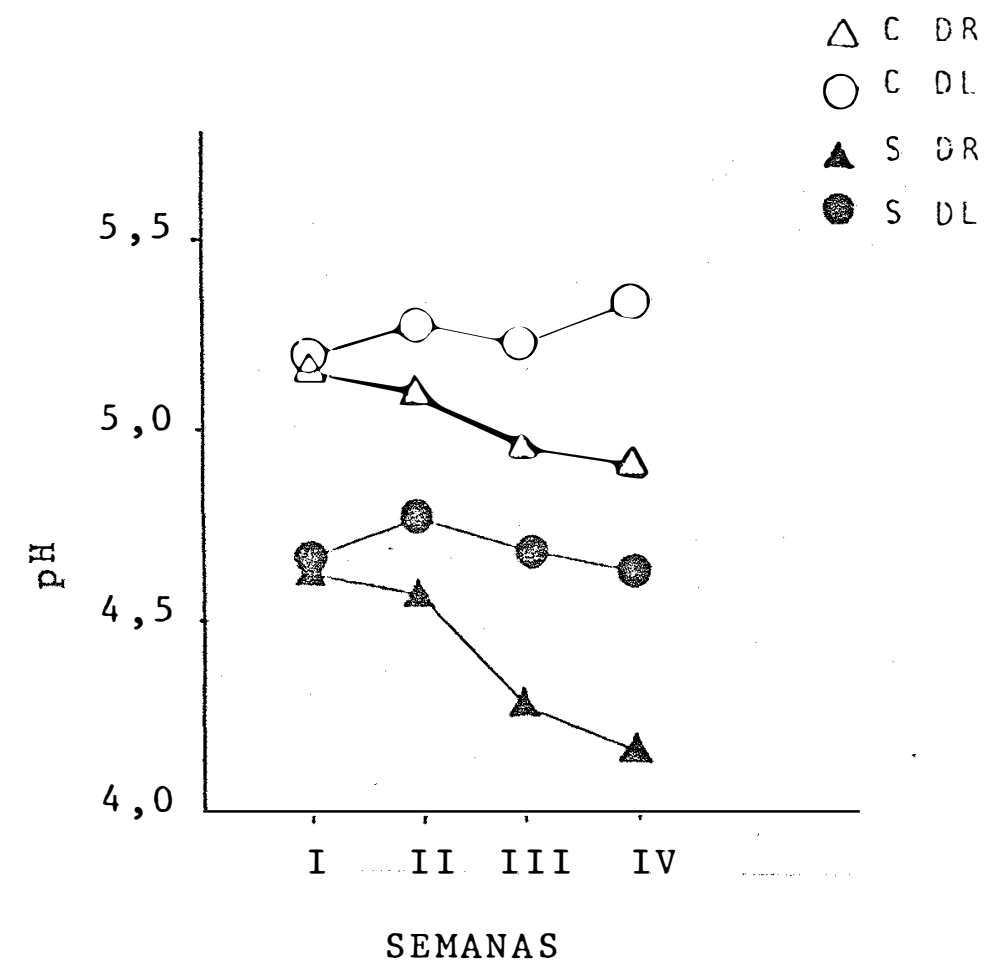

FIGURA 5: Valores de pH obtidos nos tratamentos do experimento fatorial $2^{2}$ calcário $x$ difusão 
65 .

\section{DISCUSSÃO}

A discussão dos resultados serä feita confrontando-se as hipóteses do trabalho, que foram citadas na introdução, com a interpretação dos resultados obtidos.

As hipóteses formuladas foram as seguintes:

\section{HIPÓTESE 1:}

A presença da matéria orgânica em decomposição no solo aumenta a solubilização do calcārio aplicado.

\section{HIPÓTESE 2:}

A produção de gás carbônico pela respiração de microrganismos aumenta a solubilização do calcärio.

Antes, porém, serão feitos a1guns comentärios

a respeito dos resultados obtidos, com o propósito de auxiliar a discussão principal.Esses resultados são:
a) evolução do $\mathrm{CO}_{2}$ nos diferentes tratamentos.
b) alterações no pH provocadas pela matéria orgânica. 
5.1. EVOLUÇÃO DO $\mathrm{CO}_{2}$ NOS TRATAMENTOS ESTUDADOS.

Como foi visto anteriormente (ítem 4.1.) a 1 iberação de $\mathrm{CO}_{2}$ em todos os tratamentos foi alta na primeira semana, caindo nas semanas seguintes. Essa respiração inicial elevada é consequência do räpido consumo, pelos microrganismos, dos compostos de fácil degradação presentes na matéria orgânica adicionada.

o tratamento testemunha, apesar de não ter compostos de fácil degradação, apresentou, também, uma elevação na respiração no início da incubação (QUADRo 6). Esse fato é consequência do umedecimento da terra. Quando uma amostra de solo é seca ao ar e depois umedecida, ocoxre um salto na evo1 ução do $\mathrm{CO}_{2}$, que dura alguns dias. Em seguida, há um declínio para uma baixa taxa de respiração. Ao que parece, de acordo com BLACK (1968), a secagem e umedecimento provocariam uma ruptura física no material mais resistente à decomposição, com exposição de novas superfícies e novos compostos. ABRASIMOVA (1979) cita, porēm, que o aumento na 1 iberação do $\mathrm{Co}_{2}$ é devido a decomposição de células microbianas mortas durante a secagem. A adição de calcārio, que estimula a atividade microbiana e, assim, aumenta a decomposição da matéria orgânica, pode ser também responsável pela evolução do $\mathrm{CO}_{2}$ do tratamento testemunha. Uma relação semelhante foi anteriormente demonstrada por WHITE et alii (1954) e McLEAN et alii (1967). 
Em relação aos outros tratamentos observou-se que a diferença entre eles diminuiu progressivamente, até a ültima observação (FIGURA 1). A evolução do $\mathrm{CO}_{2}$ tende ao mesmo valor em todos os tratamentos, pois o equilíbrio final deverá ser semelhante. Essa tendência ficou evidente nos tratamentos que receberam a dose de $5 \%$ de matéria orgânica (FIGURA 1A). Nos tratamentos com a dose de $10 \%$ (FIGURA 1B), a diferença maior entre os tratamentos, ao final da incubação, é atribuída à maior quantidade de substrato ainda disponível para a atividade biológica.

Na primeira semana o tratamento soja apresentou maior evolução de $\mathrm{CO}_{2}$, seguido pelos tratamentos de mi1ho, bagaço e composto, nesta ordem. Essa sequência indica a facilidade de decomposição desses materiais. Sabe-se que quando a relação C/N do material é alta a sua decomposição é mais lenta. O tratamento milho $(C / N 52,5)$, porëm, produziu mais $\mathrm{CO}_{2}$ que os tratamentos composto $(\mathrm{C} / \mathrm{N} 22,0)$ e bagaço de cana $(C / N 27,3)$, como foi visto no QUADRO 6. E provävel que a composição química do material, isto é, o teor de constituintes como celulose, hemicelulose, lignína e proteína interfira na taxa de decomposição, como foi observado por DYAL et alii (1939). A baixa respiração do tratamento composto pode ser atribuida ao fato deste material jä estar parcialmente decomposto. 
Ao final de doze semanas, porém, os tratamentos soja, composto e bagaço perderam menos $\mathrm{CO}_{2}$ que o tratamento milho (ver QUADRO 7), indicando que relações C/N mais altas determinam maior evolução de $\mathrm{CO}_{2}$, e relações mais baixas determinam menor perda de $\mathrm{CO}_{2}$. A presença de um teor relativamente mais alto de nitrogênio pode provocar menor perda de $\mathrm{CO}_{2}$, como observaram SAMPAIO e SALCEDO (1982). Esses autores, incubando solos mais palha de milho, encontraram menor evolução de $\mathrm{CO}_{2}$ nos tratamentos que receberam nitrogênio suplementar. Essa menor respiração estaria acompanhada de maior formação de biomassa microbiana, consequentemente, um teor mais alto de carbono permanece no solo na forma orgânica. Portanto, no presente trabalho, seria esperado que tratamentos com menor respiração apresentassem teores mais altos de carbono no final da incubação. De fato, como se observou (QUADRo 8) ocorreu um maior teor de carbono final e menor porcentagem de perda nos tratamentos com menor respiração.

Esses resultados, porëm, não concordam com os obtidos por AQUINO (1976) e ALBUQUERQUE (1976). Esses autores verificaram maior decomposição e menor teor de matẻria orgânica no final da incubação quando adicionaram nitrogênio à pa1ha de milho (ver item 2.2.2.4.)

o tratamento 10 B apresentou uma elevação na respiração a partir da décima semana (FIGURA 2). Não se encontrou uma explicação para esse fato. Mas, como as condições ex- 
ternas não se alteraram, é possível que esse aumento de respiração seja determinado por condições próprias do tratamento, isto é, a composição do material e suas interações com a população microbiana existente e as condições vitais oferecidas.

\subsection{ALTERAÇÕES NO PH PROVOCADAS PELA MATERIA ORGÂNICA}

$\mathrm{Na}$ apresentação dos resultados de pH (ítem 4.2.), destacou-se as diferenças de comportamento apresentadas pelos tratamentos estudados. Essas diferenças foram, provavelmente, causadas pelos tipos de compostos liberados pelos tratamentos. EIRA e CARVALHO (1970) verificaram que o tipo de material orgânico adicionado ao solo influenciava a variação de acidez; atribuiram esse fato à seleção dos microrganismos pelos principios nutricionais das fontes utilizadas. No presente traba1ho, não só a composição do material como também o pH inicial de cada tratamento (QUADRO 9) influenciaram na seleção dos microrganismos e, consequentemente, nos produtos da decomposição, provocando variações de $\mathrm{pH}$ entre os tratamentos.

As diferenças entre os efeitos das doses ( $5 \%$ e 10\%) são causadas pela quantidade dos diversos produtos 1 iberados no solo, que deve ser maior na dose de $10 \%$ de matéria orgânica. No caso do tratamento bagaço, onde a dose de $5 \%$ teve um $\mathrm{pH}$ mais elevado que a dose $10 \%$, é possível que os produtos formados sejam acidificantes. Assim, a dose $10 \%$ liberando maior quantidade desses produtos determinaria um valor mais baixo de $\mathrm{pH}$. 
No tratamento soja ocorreu uma elevação no pH nas primeiras semanas. Essa elevação ocorreu, provavelmente, devido à alta amonificação que se verifica logo no início da decomposição em material rico em nitrogênio e de fäcil decomposição, como o utilizado. A 1 iberação de $\mathrm{NH}_{4}^{+}$pela matéria orgânica tem sido apontada como um fator de aumento de pH por vários autores, como DOMMERGUES e MANGENOTT (1970) e FERRAZ (1978). O abaixamento do pH que ocorre em seguida deve-se à rápida oxidação dos íons $\mathrm{NH}_{4}^{+}$a nitrato $\mathrm{NO}_{3}^{-}$realizada por bactérias nitrificantes, processo que ocorre normalmente em solos com aeração adequada.

Mas o aumento de pH observado nos tratamentos que receberam adição de matéria orgânica não pode ser explicado apenas pela 1 iberação de íons $\mathrm{NH}_{4}^{+}$, jā que materiais com baixo teor de nitrogênio também provocaram aumentos de pH. Ácidos orgânicos produzidos durante a decomposição, retendo íons $\mathrm{H}^{+}$e $\mathrm{Al}^{3+}$, segurdo ROSATO (1978) e COSTA (1983), podem ter contribuido para essa elevação no pH, conforme o que foi comentado no ítem 2.3 .

o valor do pH no tratamento testemunha ficou abaixo de 6,0, quando se esperava que alcançasse um valor mais alto do que 6,5, considerando-se que a v\% escolhida no cálcu10 da quantidade de calcário a ser aplicada foi igual a $90 \%$. Esse baixo pH não foi causado por um acūinulo de sais, pois a condutividade elëtrica (QUADRO 15) foi baixa para esse tratamento. 
No experimento montado para verificar o efeito da restrição à difusão provocada pela presença de papel de alumínio sobre os frascos (ver ítem 4.6.), foi mostrado que esta restrição provocou um abaixamento do pH (QUADRO 16). o papel de alumínio dificultou a difusão do ar e o $\mathrm{CO}_{2}$ acumulou-se nos frascos. Como o $\mathrm{CO}_{2}$ dissolve-se na ägua, houve formação de $\mathrm{HCO}_{3}^{-}$ na solução do solo, provocando um abaixamento no pH. Nos frascos abertos houve maior difusão do $\mathrm{CO}_{2}$ e assim o efeito do $\mathrm{CO}_{2}$ foi atenuado.

os valores de $\mathrm{pH}$ e de evolução do $\mathrm{CO}_{2}$ não apresentaram correlação entre si $\left(r^{2}=0,0041\right)$, portanto não se pode afirmar que o tratamento que produziu mais $\mathrm{CO}_{2}$ tenha provocado maior abaixameinto do pH. Notou-se, porëm, que os valores de $\mathrm{pH}$ do tratamento esterilizado (QUADRO 12) ficaram em torno de 6,7 nas semanas finais, a lcançando os valores esperados.

Conjugando-se as observações e interpretações expostas acima pode-se dizer que a respiração do tratamento testemunha foi responsāvel pelo baixo valor de pH deste tratamento, ou pela diferença no pH entre os tratamentos esterilizado e testemunha.

A alteração do pH provocada pela matéria orgânica tem um aspecto importante para esse trabalho. Trata-se da utilização do pH como índice da solubilização do calcärio. Como a matéria orgânica em decomposição altera o pH, nessas con- 
dições o pH deixa de ser um bom índice para verificar a solubilização do calcārio. Alguns autores acreditam que no campo a alteração do pH é muito pequena, SMITH e BURNS (1965) mostraram que houve alterações no pH apenas a uma distância de 4 cm do material orgânico, colocado no solo. Mas a incorporação de grande massa orgânica, como na adubação verde, talvez possa alterar significativamente o pH da camada arävel, pelo menos durante a sua decomposição.

\subsection{HIPб́teSE 1: A presença no solo de matéria orgâ- nica em decomposição aumenta a solu- bilização do calcārio}

Como foi discutido anteriormente, o pH do so10 foi alterado não apenas pela adição do calcārio, mas também, pela presença de matéria orgânica em decomposição. Por essa razão o pH não serā utilizado como indicador da solubi lização do calcārio e sim os teores de cālcio e de magnésio trocáveis apresentados pelos tratamentos durante as semanas de observação.

Admitiu-se neste trabalho que o calcärio. foi a ünica fonte significativa desses elementos, a possível con tribuição dos tratamentos foi considerada desprezível.

0 aumento dos teores de $\mathrm{Ca}^{2+}$ e $\mathrm{Mg}^{2+}$ deu-se principalmente nas duas primeiras semanas, mas estendeu-se até as 
semanas IV e VI. Esses resultados indicaram reação mais lenta do calcärio em relação aos resultados encontrados por MEllo e ARZOLla (1971). Esses autores verificaram que a máxima solubilização de um calcārio dolomítico ocorreu por volta do décimo dia de incubação, com o pH atingindo 6,5. Aceitando-se que o pH e o teor de cálcio e de magnésio trocáveis podem ser utilizados como indicadores da solubilização do calcário, conforme as circunstâncias da incubação, pode-se dizer que as diferenças entre este trabalho e o conduzido por MELLo e ARZOLLA podem ser atribuídas à presença da matéria orgânica em decomposição, que determinaria a solubilização de partículas mais grosseiras por um período de tempo mais 1ongo.

Durante o período da incubação ocorreram diferentes significativas entre os tratamentos quanto aos teores de $\mathrm{Ca}^{2+} \mathrm{e} \mathrm{Mg}^{2+}$ trocāveis, especialmente entre os tratamentos composto e bagaço de cana (FIgURAS 3 e 4). Comparando-se os valores de $\mathrm{Ca}^{2+}$ e $\mathrm{Mg}^{2+}$ dos tratamentos com matēria orgânica, e o tratamento testemunha, observa-se que os tratamentos composto, milho e soja apresentaram valores mais elevados enquanto que bagaço de cana apresentou valores mais baixos. (QUADROS 10 e 11). Os três primeiros tratamentos aumentaram a solubi 1 ização do calcārio.

os teores de $\mathrm{Ca}^{2+}$ e $\mathrm{Mg}^{2+}$ do tratamento testemunha foram maiores que os teores do tratamento esterilizado (QUADRO 13). Pode-se dizer, então, que a atividade microbiana 
presente no tratamento testemunha teria provocado essa diferença. Assim, a atividade microbiana aumentou a solubilização do ca lcärio.

Ao final de doze semanas os tratamentos que receberam composto, soja e milho não apresentaram diferenças significativas, mas nota-se uma tendência do tratamento composto em apresentar valores mais elevados. 0 tipo de material orgânico que sofre a decomposição parece ter, tambëm, influência na solubilização do calcārio.

Diante do que foi exposto, a H.tPótesE 1 deve ser aceita, isto é, a matéria orgânica em decomposição aumenta a solubilização do calcärio.

5.4. HIPÓTESE 2: A produção de gäs carbônico pelos microrganismos aumenta a solubilização do calcá$\underline{\text { xio }}$

Comentou-se, no ítem 5.1, que ocorreram diferenças na produção de $\mathrm{Co}_{2}$ entre os tratamentos e, no ítem 5.2., que os resultados de $\mathrm{pH}$ do tratamento TEST indicam que pode ter havido acümulo de $\mathrm{HCO}_{3}^{-}$no solo. Segundo KHEGAY et alii (1980) o aumento da concentração de íons bicarbonato na solução do so1o promove a solubilização de carbonatos. Assim, os tratamen tos com maior produção de $\mathrm{CO}_{2}$ deveriam ter apresentado maiores valores de $\mathrm{Ca}^{2+}$ e $\mathrm{Mg}^{2+}$ trocáveis. Não houve, entretanto, cor- 
relação entre os valores de $\mathrm{CO}_{2} \mathrm{e} \mathrm{Ca}^{2+}$ trocāvel, e $\mathrm{CO}_{2}$ e $\mathrm{Mg}^{2+}$ trocāvel $\left(r^{2}=0,0859\right.$ e $r^{2}=0,0782$, respectivamente).

Quando se observa os tratamentos que receberam a dose $10 \%$ de matéria orgânica, parece ter havido um efeito negativo do $\mathrm{CO}_{2}$, pois nota-se maior solubilização nos tratamentos com menor respiração, concordando com MAlavolta (1967) (ver ítem 2.1.).

Os resultados encontrados indicam que as variações no teor de $\mathrm{CO}_{2}$ no solo não tiveram efeito sobre a solubilização do calcārio.

As modificações do pH do solo também não foram responsáveis pelas diferenças entre os tratamentos. Os tratamentos soja e composto, com alto pH inicial, apresentaram também maior solubilização do calcārio.

Não foi encontrada correlação entre os valo-

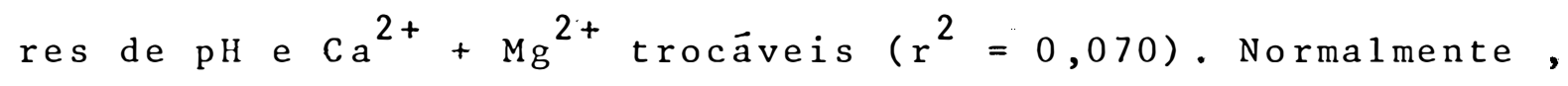
no solo existe correlação positiva entre pH e cátions trocáveis. O fato dessa correlação não ter ocorrido é devido às condições criadas pela matéria orgânica em decomposição. DOBEREINER e ALVAYDO (1966) verificaram que solo incubado com matéria orgânica não exibiu correlação entre $\mathrm{pH}$ e o teor de manganês $\left(\mathrm{Mn}^{2+}\right)$ que existe, em geral, nos solos. 
Outros produtos da decomposição podem ter importância na solubilização do calcärio, comonitratos, por exemplo. Os tratamentos soja e composto apresentaram elevada condutividade, elétrica (QUADRO 15) devido, provavelmente, a teores altos de nitratos e sulfatos. Essa afirmação é aceitāvel, especialmente considerando-se que esses dois materiais têm alto teor de nitrogênio e que as variações de pH ocorridas indicaram atividade nitrificante, principalmente para a soja, conforme comentado no ítem 5.2.

Deve-se observar, porēm, que a quantidade de nitrogênio nitrificado depende, não só do teor de nitrogênio mas tambēm, do tipo de amino-ācido presente. GUPTA e REUSZER (1967) determinaram que $4,6 \%$ do nitrogênio da soja foi nitrificado, e apenas $3,0 \%$ do nitrogênio do milho.

Dessa forma, a produção de nitratos estaria contribuindo para a solubilização do calcärio, confirmando o que foi citado por ALEXANDER (1961).

A decomposição do esterco, segundo TIBAU (1983) desenvolve reação redutora capaz de promover a solubilização de minerais como o ferro e o manganês. Esse fator pode ter determinado a maior solubilização apresentada pelos tratamentos que receberam composto.

Como não se pode estabelecer uma relação entre produção de $\mathrm{CO}_{2}$ e solubilização do calcärio, e como ë provāvel que a diferença entre os tratamentos esteja sendo 
causada por outrớs produtos da decomposição, a HIPóTESE 2 deve ser rejeitada. Os produtos da atividade microbiana aumentam a solubilização do calcārio, mas o $\mathrm{CO}_{2}$ não é o produto que determina este aumento.

\subsection{COMENTÄRIOS FINAIS}

Os resultados deste trabalho mostraram que a matéria orgânica em decomposição no solo pode provocar alterações no pH e na solubilização do calcārio.

As condições do experimento foram de laborató rio, e a quantidade de matéria orgânica aplicada foi elevada, procurando exagerar os efeitos para mostrar se seria possível ou não uma alteração na solubilização do calcário. Com base nos resultados obtidos pode-se pensar em ampliar esses estudos, modificando as condições do experimento ou introduzindo novas variàveis .

Neste trabalho, considerou-se que o aumento dos íons $\mathrm{Ca}^{2+}$ e $\mathrm{Mg}^{2+}$ deu-se apenas pela solubilização do calcārio. Mas a matéria orgânica pode ter removido da solução parte desses íns. Seria interessante estudar especificamente esse efeito. Analisar a quantidade final de carbonatos no solo pode auxiliar nessa questão. Aliās, a determinação do teor final de carbonatos, ou do teor de calcário que permaneceu no solo sem reagir é importante para se ter um balanço total dos íons cá1- 
cio e magnésio no solo (*).

Quanto à restrição imposta à livre difusão do ar, verificou-se que esta teve éfeito sobre o pH e é uma variāvel a ser considera nas incubações feitas em laboratório. Pode-se pensar ainda que, numa situação de livre difusão, as diferenças entre os tratamentos poderiam ser acentuadas. Esse ponto é mais um motivo para que se considere a matéria orgânica em decomposição influindo na solubilização do calcário.

(*) Valdomixo C. Bittencourt - Comunicação particular 
79.

\section{CONCLUSÕES}

- A presença da matéria orgânica em decomposição aumenta a solubilização do calcārio.

- Não se pode afirmar que a produção de $\mathrm{CO}_{2}$ pelos microrganismos, na decomposição da matéria orgânica, aumenta a solubilização do calcärio. 


\section{LITERATURA CITADA}

o ABRAHÃO, I.O., 1983. Rochas calcärias e sua ocorrência. Estudo Nacional do Calcário Agrícola. Piracicaba, FEALQ, $189 \mathrm{p}$.

o ABRASIMOVA, L.N., 1979. Hysteresis and temperature dependence of $\mathrm{O}_{2}$ and $\mathrm{CO}_{2}$ exchange in soil. Soviet soil. Science. Madison, $11: 343-346$.

o AlBuquerque, G.A.C., 1976. . Decomposição de resíduos orgânicos em solos arenosos medida pelo teor de carbono e relação C/N. Piracicaba, ESALQ/USP, 67 p. (Dissertação de Mestrado).

o ALEXANDER, M., 1961. Introduction to Soil Microbiology. New York, Jonh Wiley e Sons, INC. 472 p. 
o ALISSON, F.E., 1973. Soil Organic Matter and its role in, crop production. Netherlands. Elsevier Scientific Publishing Company. $637 \mathrm{p}$.

o AlmeidA, M.T., 1983. Decomposição da vinhaça incorporada ao solo (evolução do $\mathrm{CO}_{2}$ e formação de biomassa microbiana) e destino da complementação nitrogenada. Piracicaba, ESALQ/ USP, 75 p: (Dissertação de Mestrado).

O ANJOS, J.T., M. PUNDK, G. TASSINARI e S.S. GRIMM, 1981 . Efeito da calagem e da adubação fosfatada sobre algumas propriedades químicas de um cambissol hūmico-diströfico cultivado com milho. Revista Brasileira de Ciência do Solo, Campinas, $5: 50-54$.

o ANDERSON, C.A., 1969. Effect of particie size of calcitic and dolomitic 1 imestone on rate of reaction in Lakeland fine sand. Procedings of Soil Crop. Science Society of Florida, F1orida, 28 : 63-69.

o AQuino, B.F., 1976. Decomposição de resíduos orgânicos em solos argilosos medido pelo teor de matéria orgânica e relação C/N. Piracicaba, ESALQ/USP, 67 p. (Dissertação de Mestrado).

o ASSUMPÇÃo, e., 1981. Ação da população microbiana natural de um Regossolo do Estado de São Paulo, influenciada pela adição de uma fonte de matéria orgânica sobre um fosfato 
natural. Piracicaba ESALQ/USP, 39 p. (Dissertação de Mestrado).

o BARBER, S.A., 1967. Liming materials and Practices. In: PEARSON, R.W. e F. ADAMS, ed. Soil Acidity and Liming. Madison, American Society of Agronomy Publisher, p. 125-160.

o BARNES,E.E., 1947. A new method for estimating the surface of 1 iming material and other insoluble calcium compounds. Soil Science. Baltimore, 63: 285-289.

o BEAR, F.E., 1963. Suelos y fertilizantes, 20 ed. Barcelona, Ediciones Omega S.A. 458 p.

o BECKMAN, H. e H.W. SCHARPENSEEL, 1964. Carbon dioxide release from sterlized soil. Soils and Fertilizers, Commonwealth Bureau of Soils, 27: 483

o Bellingieri, P.A., 1983. Avaliação em laboratório da eficiência de diferentes frações granulométricas de calcärios agrícolas. Piracicaba, ESALQ/USP, 99 p. (Tese de Doutoramento).

o BLACK, C.A., 1968. Soil - Plant Relationships, $2^{\text {nd }}$ ed. New York, Jonh Wiley \& Sons, INC. 792 p.

o CAMARgo, A.P. 1972. Influência da granulometria de três materiais corretivos na neutralização da acidez do solo. Piracicaba, ESALQ/USP, 59 p. (Dissertação de Mestrado). 
o CARvalho, P.C.T., J.M. SAlgado e E.P. SANTANA, 1977. Biotransformação da apatita de Araxă em solo suplementado com diferentes fontes de carbono. O Solo, Piracicaba, 69: $30-34$.

o COLEMAN, N.T. e G.W. THOMAS, 1967. The basic chemisty of soil acidity. In: PEARSON, R.W. e F. ADAMS, ed. Soil, Acidity and Liming. Madison, American Society of Agronomy, Publisher, 274 p.

o CORBET, A.S., 1975. Biological Processes in Tropical Soils. with special reference to Malaysia. Cambridge, W. Heffer \& Sons LTD. $15 \dot{6}$ p.

o Costa, M.P., 1983. Efeito da matéria orgância em alguns atributos do solo. Piracicaba. ESALQ/USP, 137 p. (Dissertação de Mestrado).

o DOBEREINER, J. e R. ALVAHYDo, 1966. Eliminação da toxidez de manganês pela matéria orgânica em solo "gray hidromórfico". Pesquisa Agropecuária Brasileira. Rio de Janeiro, 1 : 243-248.

o DOMMERGUES, Y. e F. MANGENOT, 1970. Ecologie microbienne. du so1. Paris, Masson, 796 p.

o DUFF, R.B., D.M. WEBLEY e R.0. SCOTT, 1963. Solubilization of minerals and related materials by 2 - Ketogeuconic acid producing bacteria. Soil Science, Baltimore, 95:105-114. 
o DYAL, R.S., F.B. SMITH e R.V. ALLISON, 1939. The decomposition of organic matter in soils at different initial pH. Journal of the American Society of Agronomy, Washington, 31 : $841-850$.

o EIRA, A.F. e P.C.T. CARVALho, 1970. A decomposição da matéria orgânica pelos microrganismos do solo, e sua influência nas variações do pH. Revista da Agricultura, Piracicaba, 45: 15-21.

o FASSBENDER, H.W., 1984. Química de suelos con énfasis en suelos de America Latina, 49 ed. Costa Rica. Instituto Interamericano de Cooperação para 1 a Agricultura, 398 p.

o FERRAZ, J.M.G., 1978. Influência da vegetação sobre a população microbiana e fertilidade dos solos de cerrado. Piracicaba, ESALQ/USṔ, $93 \mathrm{p}$. (Dissertação de Mestrado).

o GAllo, J.R. (1954). Estudo da solubilidade em solução de ácido acético a $1 \%$ de alguns materiais calcário de grau de finura comercia1. Bragantia, Campinas, 13: 133-139.

o GALlo, J.R. e R.A. CATANI, 1954. Solubilidade de alguns tipos de calcários. Bragantia, Campinas, 13: 63-74.

o GERRETSEN, F.C., 1948. Microorganisms on the phosphate intake by the plant. Plant and Soil, The ague, 1: 51-81.

o GUPTA, V.C. e H.W. REUSZER, 1967. Effect of p1ant species on the amino acid content and nitrification of soil organic matter. Soil Science, Ba1timore, 104: 395-400. 
o HASSET, J.J., D.W. GREGG, J.B. FEHRENBAHER, 1976 . Formation of calcium carbonate concretions in natric horizons of I1iinois soils. Soil Science, Baltimore, 122: 202-206.

o JENKINSON, D.S., 1966. Studies on the decomposition of plant material in soil.II. Partial sterilization of soil and the soil biomass. Journal of Soil science, Oxford, $17: 280-302$

o HAYMAN, D.S. Phosphorus Cycling by soil microrganisms and Plant Roots, 1975. In WALKER, N. ed. Soil Microbiology. A critical review. Londres, Butterworths \& Co. Ltd. p. $67-92$.

o KHEGAY, T.A., V.V. RACHINSKIY e A.S. PEL'TTSER, 1980. Sorption of Carbon Dioxide by Soils. Soviet Soil Sciénce, Madison, $\underline{12}: 56-63$

o LOUW, H.A. e D.M. WEBLEY, 1959. A study of soil bacteria dissolving certain mineral phosphate fertilizers and related compounds. Journal of Applied Bacteriology, Great Britain, $22: 227-233$.

o MAlavolta, E., 1967. Manual de Química Agrícola - Adubos e Adubação 20 ed. São Paulo, Editoŕa Agronomica Ceres, $606 \mathrm{p}$. 
o MAYAUDON, J., 1971. Use of Radio-respirometry in soil microbiology and biochemistry. In: McLAREN,A.D. e J.SKUJINS, ed..Soil Biochemistry vol. II. New York, Marce1 Dekker, INC. $202-256$.

o McLEAN, A.J., J.J. JASMIN e R.L. HASTER, 1967. Effect of 1 ime on potato crops and properties of a sphagnum peat soil. Canadian Journal of Soil Science, Otawa, 47: 89-84.

o MEllo, F.A.F. e S. ARZOLla, 1971. A solubilização do magnésio do calcārio dolomítico no solo. I - Ensaios de Laboratório. Revista de Agricultura, Piracicaba, 46: 129-136.

o MEYER, T.A. e G.W. VOLK, 1952. Effect of particle size of limestone on soil reaction, exchangeable cations and plant growth. Soil Science, Baltimore, 73: 27-52

o MILLER, R.D. e D.D. JOHNSON, 1964. The effect of soil moisture tension on carbon dioxide evolution, nitrication and nitrogen mineralization. Soil science society of America Proceedings, Madison, 28: 644-647.

o MORGAN, M.F. e R.M. SALTER, 1923. Solubility of 1 imestone as related to their physical properties, Soil science, Baltimore, 16: 293-305.

o NEVES, M.C.P.,I.T. LIMA e J. DOBEREINER, 1983. Efeito - da vinhaça sobre a microflora do solo. Revista Brasileira de Ciência do Solo, Campinas 7: 131-136. 
o PARKINSON, D., T.R.G. GRAY e S.T. WILLIANS, 1971. Methods. for studing the ecology of soil micro-organisms. IBP

Handbook no 19. Oxford, Black-wel1 Scientific Publications.. $116 \mathrm{p}$.

o Pimentel, G.C., 1966. Chemistry, an experimental science. 50. San Francisco, W.H. Freeman and company, Cooperating Publishers. 466 p.

o QUAGgio, J.A., 1983. Critérios para calagem em solos do Estado de São Paulo. Piracicaba, ESALQ/USP, 76 p. (Dissertação de Mestrado).

o RAIJ, B. van, 1977. Estudo de materiais calcārios usados como corretivos do solo no Estado de São Paulo IV - 0 poder relativo de neutralização total. Bragantia, Campinas 36: $139-145$.

o RAIJ, B. van H. CANTARElla, A. P. CAMARgO e E. SOARES 1982 . Perdas de cálcio e magnésio durante cinco anos em ensaio de calagem. Revista Brasileira de Ciência do Solo, Campinas 6: $33-37$.

o RANZANI, G.0. FREIRE e T. KINJO, 1966. Carta de Solos do Município de Piracicaba. Piracicaba, Centro de Estudo de Solos, ESALQ/USP, 85 p.

o RESCHER, R., 1964. Introduction to Logic. New York, St. Martin's Press. 360 p. 
o Rosato, F.M., 1978. Efeito da calagem e da matéria orgânica sobre a acidez de cinco solos do município de Piracicaba. Piracicaba, ESALQ/USP, 43 p. (Dissertação de Mestrado).

o RUSSELL, E.J. e E.W. RUSSELL, 1964. Las condiciones de 1. suelo y el desarrollo de 1 as plantas. Espanha, Aguilar S.A. de Ediciones. 771 p.

o SAMPAIO, E.V.S.B. e I.H. SALCEDO, 1982. Decomposição da palha de milho marcada e incorporação do ${ }^{14} \mathrm{C}$ à biomassa microbiana de um 1 atossol vermelho amarelo. Revista Brasileira de Ciência do Solo, Campinas, 6: 29-32.

o SCHOLlENBERGER, C.J. e R.M. SALTER, 1943. A chart for evaluating agricultural 1 imestone. Journal of American. Society of Agronomy, Washington, 35: 955-966.

o SMITH, J.H. e G.R. BURNES 1965. Ion Gradients and Nitrification Associated with Decomposition of a Plant Material Layer in soil. Soil Science Society of America Proceedings, 29: $179-181$.

o SOUZA, E.A. e A.M.L. NEPTUNE, 1979. Efeito da granulometria de calcārio dolomítico sobre propriedades químicas de um 1atossolo. Revista Brasileira de Ciência do Solo, Campinas; 3 : $120-125$.

o SREERAMUCU, U.S. e P.F. PRATT, 1970. Influence of various treatmens on the dissolution of dicalcium phosphate in soils. Soil Science, Baltimore, 109: 186-189. 
o STANIER, R.Y., M. DOUDOROFF e E.A. ADELBERG, 1969. Mundo dosmicróbios. São Paulo: Editora Edgard Blucher LTdA, 741 p.

o STEVENSON, F.J., 1967. Organic acids in soil. In: Mc LAREN, A.D. e PETERSON, G.H., ed. Soil Biochemistery vol. I. New York Marcel Dekker, INC. p. 119-146.

o SWABY, R.J. e J. SHERBER, 1958. Phosphate-dissolving microorganisms in the rhizosfere of legumes. In: HALLOWORTH, E.G. ed. Nutrition of the legumes. Butterworths Scientifics Publicent.

o SWARTZENDRUBER, D. e S.A. BARBER 1965. Dissolution of limestone particles in soil. Soil science, Baltimore, 100: $287-291$

o THOMAS, R.P. e H.M. GROSS, 1952. A method of estimating the reacting rate of differente particle size of 1 imestone. Soil Science, Baltimore, 73 : 53-59.

o THOMPSON, C.M. e F.R. THOEH, 1973. Soils and soil fertility, 39 ed. New York, McGraw-Hi11, 495 p.

o TIBAU, A.Q. 1983. Matëria orgânica e fertilidade do solo. 29 ed. São Paulo, Livraria Nobe1, 220 p. 
o WAGNER, E.H., 1975 . Microbial growth and carbon turnover In: PAUL, E.A. e A.D. McLAREN, ed. Soil Biochemistry vol. III, New York. Marcel Bekker, INC. p. 269-305.

o WAKSMAN. A. e F.G. TENNEY, 1928. Composition of natural organic materiais and their decomposition in soil. III the influence of nature of plant upon the rapidity of its decomposition. Soil Science,Baltimore, 26: 155-171.

o WAKSMAN, S.H., 1952. Soil Microbiology. New York, Jonh Wiley \& Sons, INC. 356 p.

o WHITE, J.M., F.J. HOLBEN e C.D. JEFFRIES, 1934: Influence of soil acidity upon de decomposition of organic matter in soils. Soil Science, Baltimore, 37: 1-15.

o WUNSCHE, W.H. e H. BOHNEN, 1976. Avaliação da dissolução de varias frações de calcário dolomítico em oxissol do Rio Grande do Sul. Agronomia Sulriograndense, Porto Alegre, $12: 173-178$.

o WUTKE, A.C.P. 1972 .. Acidez. In: MONIZ, A.C. coord. Elementos de Pedologia São Paulo, Editora Poligono, 459 p. 